\title{
An unanticipated early function of DEAD-box ATPase Prp28 during commitment to splicing is modulated by U5 snRNP protein Prp8
}

\author{
ARGENTA M. PRICE, ${ }^{1}$ JANINA GÖRNEMANN, ${ }^{2,3,4}$ CHRISTINE GUTHRIE, ${ }^{1,5}$ and DAVID A. BROW ${ }^{2,5}$ \\ ${ }^{1}$ Department of Biochemistry and Biophysics, University of California, San Francisco, California 94143, USA \\ ${ }^{2}$ Department of Biomolecular Chemistry, School of Medicine and Public Health, University of Wisconsin, Madison, Wisconsin 53706, USA \\ ${ }^{3}$ Max Planck Institute of Molecular Cell Biology and Genetics, 01307 Dresden, Germany
}

\begin{abstract}
The stepwise assembly of the highly dynamic spliceosome is guided by RNA-dependent ATPases of the DEAD-box family, whose regulation is poorly understood. In the canonical assembly model, the U4/U6.U5 triple snRNP binds only after joining of the U1 and, subsequently, U2 snRNPs to the intron-containing pre-mRNA. Catalytic activation requires the exchange of U6 for U1 snRNA at the 5' splice site, which is promoted by the DEAD-box protein Prp28. Because Prp8, an integral U5 snRNP protein, is thought to be a central regulator of DEAD-box proteins, we conducted a targeted search in Prp8 for cold-insensitive suppressors of a coldsensitive Prp28 mutant, prp28-1. We identified a cluster of suppressor mutations in an N-terminal bromodomain-like sequence of Prp8. To identify the precise defect in prp28-1 strains that is suppressed by the Prp8 alleles, we analyzed spliceosome assembly in vivo and in vitro. Surprisingly, in the prp28-1 strain, we observed a block not only to spliceosome activation but also to one of the earliest steps of assembly, formation of the ATP-independent commitment complex 2 (CC2). The Prp8 suppressor partially corrected both the early assembly and later activation defects of prp28-1, supporting a role for this U5 snRNP protein in both the ATP-independent and ATP-dependent functions of Prp28. We conclude that the U5 snRNP has a role in the earliest events of assembly, prior to its stable incorporation into the spliceosome.
\end{abstract}

Keywords: pre-mRNA splicing; Prp28; Prp8; commitment complex; pre-spliceosome

\section{INTRODUCTION}

The spliceosome is a macromolecular machine that locates and excises introns with single-nucleotide precision. To accurately identify and remove introns, the spliceosome undergoes a stepwise series of binding events and conformational rearrangements, guided by proteins of the $\mathrm{DExD} / \mathrm{H}$-box family of RNA-dependent ATPases. In the canonical model of spliceosome assembly (for review, see Will and Lührmann 2011) the U1 snRNP first recognizes the $5^{\prime}$ splice site (5'ss), forming commitment complex 1 (CC1). The branch site and $3^{\prime}$ end of the intron are then recognized by two proteins, BBP and Mud2 in yeast, forming commitment complex 2 (CC2). Next, the first ATP-dependent step of splicing occurs: DEAD/DECD-box proteins Prp5 and Sub2 promote rearrangements that replace BBP and Mud2 with the U2 snRNP at the branch site, forming the pre-spliceosome or A com-

\footnotetext{
${ }^{4}$ Present address: Department of Cellular and Molecular Medicine, KU Leuven, BE-3000 Leuven, Belgium

${ }^{5}$ Corresponding authors

E-mail christineguthrie@gmail.com

E-mail dabrow@wisc.edu

Article published online ahead of print. Article and publication date are at http://www.rnajournal.org/cgi/doi/10.1261/rna.041970.113.
}

plex. The U4/U6.U5 triple-snRNP (tri-snRNP) then joins to form the assembled spliceosome or B complex.

Once assembled, the spliceosome undergoes activation for catalysis. DEAD-box protein Prp28 promotes release of the U1 snRNP, allowing U6 to base-pair with the 5'ss. In coordination with Prp28, DEIH-box helicase Brr2 (a stable component of the U5 snRNP) unwinds U4 from U6, allowing U6 to base-pair with U2. Together, these ATP-dependent activities of Prp28 and Brr2 form the U2/U6.U5 spliceosome (B ${ }^{\text {act }}$ complex) competent for the final steps of activation, which include binding of the NineTeen Complex (NTC) and additional rearrangements catalyzed by the DEAH-box protein Prp2. While this general sequence of events is well supported, several studies have also implicated the U5 snRNP in very early steps of spliceosome assembly, before stable incorporation of the tri-snRNP (Wassarman and Steitz 1992; Wyatt et al. 1992; Newman et al. 1995; Ast and Weiner 1997; Maroney et al. 2000). In addition, the mechanisms underlying the

\footnotetext{
(c) 2013 Price et al. This article is distributed exclusively by the RNA Society for the first 12 months after the full-issue publication date (see http:/ rnajournal.cshlp.org/site/misc/terms.xhtml). After 12 months, it is available under a Creative Commons License (Attribution-NonCommercial 3.0 Unported), as described at http://creativecommons.org/licenses/by-nc/3.0/.
} 
timing and coordination of each assembly step remain poorly understood. In this study, we focus on Prp28 and its interactions with Prp8, an integral component of the U5 and trisnRNPs, thought to be a central regulator of spliceosome activity (Kuhn et al. 2002; Grainger and Beggs 2005; Galej et al. 2013).

Several studies have provided evidence that Prp28 promotes U1 snRNP release and is involved in stable tri-snRNP incorporation into the spliceosome. The cold-sensitive prp28-1 mutation, G279E, is in motif $1 \mathrm{~b}$ of the DEAD-box domain (Strauss and Guthrie 1991, 1994), which likely contacts an as yet unknown RNA substrate (Fairman-Williams et al. 2010). It causes a broad splicing defect (Pleiss et al. 2007) and exacerbates mutations that hyperstabilize the base-pairing between U1 and the 5'ss (Staley and Guthrie 1999). Other mutations in Prp 28 reduce fidelity of U6/5'ss base-pairing, the interaction that replaces U1/5'ss pairing (Yang et al. 2013). Further supporting a role in U1 snRNP release, Prp28 is nonessential in strains with mutations that are predicted to destabilize the U1/5'ss interaction (Chen et al. 2001; Hage et al. 2009; Schwer et al. 2013). Finally, U1/5'ss hyperstabilization and prp28-1 cause similar in vitro spliceosome assembly defects, which include inhibition of U4/U6 unwinding and reduced stability of tri-snRNP association (Staley and Guthrie 1999). In mammalian cells, Prp28 is a stable component of the tri-snRNP (Teigelkamp et al. 1997) and is directly involved in its recruitment to the spliceosome (Ismaili et al. 2001; Mathew et al. 2008). However, yeast Prp28 appears to be less stably associated with tri-snRNP (Strauss and Guthrie 1994; Gottschalk et al. 1999; Stevens et al. 2001; Small et al. 2006), so it is unclear whether the defect in tri-snRNP incorporation in the prp28-1 strain is direct or is an indirect consequence of the block to U1 snRNP release.

The Prp28- and Brr2-catalyzed releases of the U1 and U4 snRNPs appear to be coordinated: mutations that inhibit either step also block the other (Kuhn et al. 1999; Staley and Guthrie 1999). Prp8 is a good candidate for regulating Prp28 and coordinating its activity with that of Brr2. The Jab1/MPN domain at the $\mathrm{C}$ terminus of Prp8 is known to regulate Brr2 activity (Maeder et al. 2008; Mozaffari-Jovin et al. 2012, 2013). Furthermore, the $\mathrm{N}$-terminal domain (NTD) of Prp8 harbors a mutation that suppresses the cold-sensitivity of the prp28-1 mutation (Kuhn et al. 2002) and also physically interacts with two U1 snRNP proteins (Abovich and Rosbash 1997; van Nues and Beggs 2001). A recent study found that Prp8 cross-links to the U1 snRNA, and mutations in U1 that reduce this cross-link also reduce triplesnRNP association with the pre-mRNA ( $\mathrm{Li}$ et al. 2013). Therefore, Prp8 is perfectly positioned to promote tri-snRNP joining through interactions with $\mathrm{U} 1$ and then regulate Prp28-directed-U1 release.

To define Prp28's interaction with Prp8, we conducted a targeted selection for cold-insensitive suppressors of prp28-1 in the Prp8-NTD. We identified 15 suppressor substitutions that cluster in a proposed bromodomain (Dlakić and
Mushegian 2011). To determine the precise order of spliceosome assembly defects caused by prp28-1 and to identify which defects are suppressed by the Prp8 alleles, we monitored the kinetics of cotranscriptional spliceosome assembly in vivo and post-transcriptional spliceosome assembly in vitro. As expected, prp28-1 blocks U1 and U4 release and reduces stable tri-snRNP association. Surprisingly, however, prp28-1 also inhibits formation of the pre-spliceosome and ATP-independent CC2. Therefore, we propose that $\operatorname{Prp} 28$ has at least two distinct roles in spliceosome assembly and activation: an ATP-independent role in CC2 formation and a subsequent ATP-dependent role in U1 release. A prp28-1suppressor mutation in the PRP8-NTD partially alleviates all of the spliceosome assembly and activation defects caused by prp28-1, including the early CC2 formation defect. Our results provide evidence that Prp8 and the U5 snRNP have a role in the earliest events of spliceosome assembly, prior to the stable incorporation of the tri-snRNP into the spliceosome.

\section{RESULTS}

\section{prp8-tes alleles: substitutions in the N-terminal quarter of Prp8 that suppress prp28-1}

In order to characterize the interactions between Prp28 and its potential regulator, Prp8, we screened the NTD of Prp8 for suppressors of prp28-1. Prp8 is a $280-\mathrm{kDa}$ protein that is an integral component of the U5 and tri-snRNPs. Substitutions in distinct regions of Prp8 suppress mutations in a variety of spliceosomal proteins as well as mutations in snRNAs and conserved splice signals in the pre-mRNA itself (Grainger and Beggs 2005). Recent studies have provided deep insight into the structure of the C-terminal two-thirds of Prp8 (Galej et al. 2013). The C-terminal domains of Prp8 contact the $5^{\prime}$ ss with an RNase-H-like fold (Pena et al. 2008; Ritchie et al. 2008; Yang et al. 2008; Schellenberg et al. 2013) and regulate Brr2 through a Jab/MPN domain (Pena et al. 2007; Maeder et al. 2008; Mozaffari-Jovin et al. 2012, 2013). The N-terminal portion of Prp8 remains structurally elusive, but is particularly interesting in connection with Prp28. In a prior selection for suppressors of a cold-sensitive mutation in U4 RNA (U4-cs1) that blocks U4 and U1 release at $16^{\circ} \mathrm{C}$, we isolated an $\mathrm{N}$-terminal Prp8 substitution (L280P) that suppressed both U4-cs1 and prp28-1 (Kuhn et al. 2002). This substitution was the only U4-cs1-suppressor of 13 tested that also suppressed prp28-1, implying that suppression of prp28-1 is due to alteration of a specific interaction rather than a general effect of decreased Prp8 activity.

Therefore, we sought to map this interaction surface in the $\mathrm{N}$-terminal quarter of Prp8 by mutagenizing codons 1-660 of PRP8 by error-prone PCR and selecting alleles that allow a prp28-1 strain to grow at $16^{\circ} \mathrm{C}$ (Fig. 1A,B; Table 1). Thirty-seven cold-resistant clones were isolated, 16 of which contained the substitution D273G, either as the sole substitution (eight clones) or as one of two or more substitutions. 
A Prp8

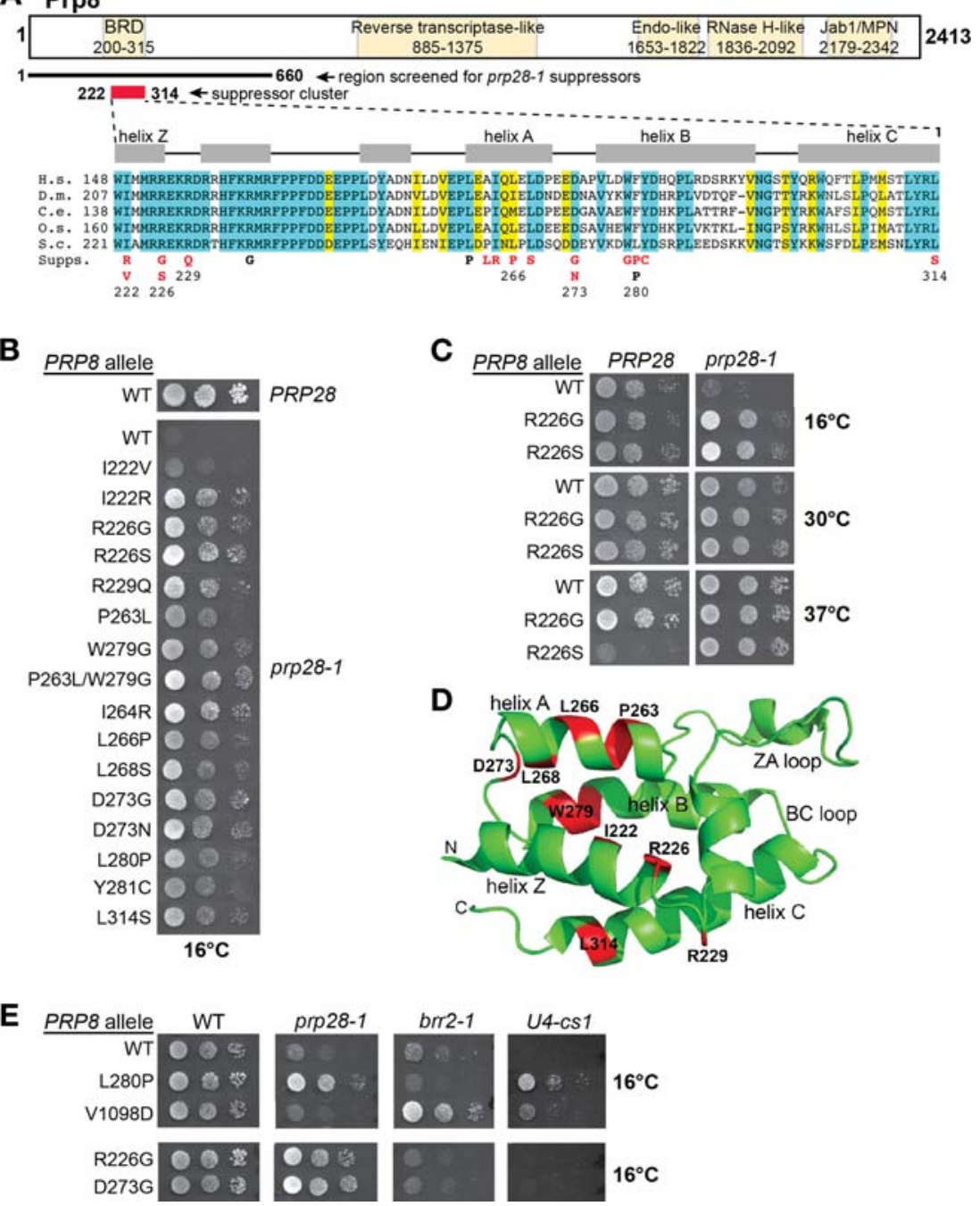

FIGURE 1. Suppressors of prp28-1 selected in the N-terminal quarter of Prp8. (A) Map of Prp8, showing domains identified by sequence or structural homology (Grainger and Beggs 2005; Dlakić and Mushegian 2011; Galej et al. 2013). Numbers indicate amino acid residues. (BRD) Bromodomain-like (Dlakić and Mushegian 2011). The region that was screened for prp28-1-suppressor mutations and the subregion in which such mutations were obtained are indicated. Sequences of human (H.s.), fly (D.m.), worm (C.e.), rice (O.s.), and budding yeast (S.c.) Prp8 are shown below, aligned in the region containing suppressor mutations, with the position number of the first residue and selected altered residues indicated. Residues highlighted in blue are identical in all five sequences, while those highlighted in yellow are highly similar. Substitutions that suppress prp28-1 are shown in red below the alignment, and substitutions that suppress U4-cs1 (Kuhn and Brow 2000) are shown in black. Locations of putative $\alpha$-helices (see $D$ ) are indicated above the sequences. (B) prp8-tes alleles suppress the cold-sensitive growth defect of prp28-1. Tenfold serial dilutions of wild-type, prp28-1/PRP8, and the indicated prp28-1/prp8-tes strains were spotted on YEPD medium and incubated at $16^{\circ} \mathrm{C}$ for $10 \mathrm{~d} .(C)$ The prp8-R226S mutation confers a heat-sensitive growth defect that is suppressed by prp28-1. Another substitution at the same position, prp8-R226G, is not heat sensitive. Tenfold serial dilutions on YEPD are shown. $(D)$ Location of prp8-tes substitutions mapped onto a structural model of the putative Prp8 bromodomain (model from Dlakić and Mushegian 2011). Residues altered by prp8-tes mutations are shown in red and selected residues and secondary structure elements are labeled. (E) prp8-tes mutations do not suppress the cold-sensitive phenotype caused by mutations in BRR2 or the U4 RNA gene. Tenfold serial dilutions of strains were spotted on YEPD medium and incubated at $16^{\circ} \mathrm{C}$ for $10 \mathrm{~d}$, except for U4-cs1 strains $\left(18^{\circ} \mathrm{C}\right.$ for $\left.12 \mathrm{~d}\right)$. Controls prp8-L280P and prp8-V1098D behaved as in Kuhn et al. (2002).
Three additional suppressors contained a D273N substitution, once as the sole mutation. Seven clones had an R226G substitution, in two cases as the sole mutation, and another clone had the R226S substitution. Of the remaining 10 clones, three had at least one substitution between residues 222 and 229, six had at least one change between residues 263 and 281, and one had the substitution L314S. Silent (synonymous) and secondary mutations spanned codons $20-595$ in the mutagenized region, indicating that the tight clustering of the suppressor mutations is not an artifact of the PCR mutagenesis or in vivo recombination. Furthermore, the most common suppressor mutations were isolated in three independent selections; therefore, it is unlikely that they were over-represented in the mutant pool by chance.

Working from the collection of suppressor alleles, we generated $P R P 8$ alleles containing 15 different single amino acid substitutions at 12 positions between residues 222 and 314 . We refer to these collectively as "prp8-tes" alleles, for twenty-eight-1 suppression. The prp8-tes alleles were scored for their strength of suppression of prp28-1 (Fig. 1B; Table 1). P263L and W279G gave stronger suppression when present in combination, as isolated in the selection, than when present individually. The previously isolated L280P substitution conferred a level of cold-resistant growth similar to that of the newly selected suppressors of prp28-1.

To assess the general effects of the suppressor substitutions on Prp8 function, we also tested the prp8-tes alleles for growth phenotypes in the presence of wild-type PRP28. The R226S substitution conferred a strong heat-sensitive growth defect at $37^{\circ} \mathrm{C}$, but supported normal growth at $16^{\circ} \mathrm{C}$ and $30^{\circ} \mathrm{C}$ (Fig. 1C). All other substitutions exhibited no qualitative growth defect at $16^{\circ} \mathrm{C}, 30^{\circ} \mathrm{C}$, or $37^{\circ} \mathrm{C}$. Importantly, the prp8-R226S, prp28-1 double-mutant strain was not heat sensitive (Fig. 1C), indicating that these two mutations mutually suppress one another.

Of the 12 residues altered by prp8-tes mutations, nine are invariant in yeast, rice, fruit fly, worm, and human Prp8 
TABLE 1. Suppressors of prp28-1 in the N-terminal quarter of Prp8

\begin{tabular}{lccr}
\hline Substitution & $\begin{array}{c}\text { No. of } \\
\text { independent } \\
\text { clones }\end{array}$ & $\begin{array}{c}\text { Isolated as } \\
\text { single } \\
\text { substitution }\end{array}$ & $\begin{array}{r}\text { Strength of } \\
\text { suppression }\end{array}$ \\
\hline I222R & 1 & 1 & +++ \\
I222V & 1 & 1 & + \\
R226G & 7 & 2 & +++ \\
R226S & 1 & 0 & ++++ \\
R229Q & 1 & 0 & +++ \\
P263L & 1 & $0^{a}$ & ++ \\
I264R & 1 & 0 & ++++ \\
L266P & 1 & 0 & ++ \\
L268S & 2 & 2 & +++ \\
D273G & 16 & 8 & ++++ \\
D273N & 3 & 1 & ++++ \\
W279G & 1 & $0^{a}$ & +++ \\
L280P & NA & NA & ++ \\
Y281C & 1 & 0 & ++ \\
L314S & 1 & 0 & +++ \\
P263L/W279G & 1 & NA & ++++ \\
\hline
\end{tabular}

(NA) Not applicable.

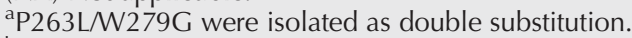

Identified previously (Kuhn et al. 2002).

(Fig. 1A), consistent with an important function. Intriguingly, the region encompassing the prp8-tes substitutions corresponds to a recently proposed bromodomain (BRD) in Prp8 (Dlakić and Mushegian 2011). Bromodomains bind acetylated lysine residues in histones and other proteins (Filippakopoulos and Knapp 2012). The putative Prp8 bromodomain lacks several residues important for acetylated-lysine binding (Dlakić and Mushegian 2011) and so may serve as a general protein-protein interaction domain instead. Strikingly, when the suppressor residues are mapped on the structural model of the bromodomain from Dlakic and Mushegian (2011), the residues cluster tightly in the four $a$-helices of a helical bundle (Fig. 1D), in contrast to their dispersal in the primary structure. All but three of the 15 substitutions substantially alter the side-chain structure, and thus are likely to destabilize the putative four-helix bundle itself and/or its interaction with another protein or RNA.

\section{Substitutions in Prp8 that suppress prp28-1 do not generally suppress U4-cs1}

Since the original prp28-1 suppressor, Prp8-L280P, was isolated in a selection for suppressors of the cold sensitivity of U4-cs1, we hypothesized that mutations in the Prp8-NTD that decrease reliance of the spliceosome on Prp28 may also counteract the effects of U4-cs1. To test this hypothesis, we assessed the ability of prp8-tes alleles to suppress U4-cs1. None other than L280P suppressed U4-cs1, nor did any suppress the cold-sensitive growth phenotype conferred by brr2-1, which blocks U4 release (Fig. 1E; Raghunathan and Guthrie 1998; data not shown). This result indicates that suppression of the growth defect of prp28-1 is not sufficient for suppression of U4-cs1, and suggests that L280P is unusual in its ability to suppress both mutations.

\section{prp8-tes substitutions do not promote $\mathrm{U} 1 / 5^{\prime}$ ss destabilization or alter the interaction of Prp8-NTD with Prp39, Prp40, or Prp28 in vitro}

We next tested the hypothesis that disruption of Prp8-U1 snRNP interactions by the prp8-tes alleles could bypass the growth requirement for Prp28 function. The prp8-tes mutations cluster in a potential protein-protein interaction interface, and the Prp8-NTD is known to interact with U1 snRNP proteins Prp39 and Prp40 (Abovich and Rosbash 1997; van Nues and Beggs 2001). Further, Prp28 is nonessential in the presence of mutations in U1 snRNP proteins or the U1 snRNA that are expected to destabilize the U1/5'ss interaction (Chen et al. 2001; Hage et al. 2009; Schwer et al. 2013). Therefore, if loss of Prp8-U1 interactions similarly leads to destabilization of U1 snRNP from the $5^{\prime}$ ss, they might bypass the requirement for Prp28. However, we found that a prp8-tes allele did not rescue the lethality caused by a complete absence of $\operatorname{Prp} 28$ protein or by a substitution predicted to destroy the catalytic activity of Prp28 (prp28-D341N) (Fig. 2A). Nor did a prp8-tes allele suppress the low-temperature growth defect caused by hyperstabilization of U1/5'ss basepairing (Fig. 2B). These results indicate that prp8-tes alleles do not significantly destabilize the U1/5'ss interaction.

To more directly test the effect of prp8-tes alleles on binding of the Prp8-NTD to Prp39 or Prp40, we used in vitro binding assays. An N-terminal fragment of Prp8 (Prp8 residues 1-330) with an $\mathrm{N}$-terminal glutathione S-transferase (GST) tag and either wild-type sequence or one of three prp8-tes substitutions was expressed in E. coli. Full-length Prp39 and Prp40 with C-terminal $\mathrm{His}_{6}$ tags were also expressed in E. coli. Using a standard GST pull-down method, we reproduced the known interactions of the Prp8-NTD with Prp39 and Prp40. However, wild-type Prp8-NTD and the three prp8-tes alleles all pulled down similar amounts of both Prp39 and Prp40 (Fig. 2C). Taken together, our results indicate that prp8-tes alleles suppress prp28-1 by a means other than altering interactions between Prp8 and Prp39 or Prp40, or by directly promoting destabilization of the U1/ 5 'ss interaction.

If the prp8-tes mutations are not suppressing prp28-1 indirectly by destabilizing the U1 snRNP- $5^{\prime}$ splice-site interaction, they may be acting directly by altering a Prp8-Prp28 interaction. Although a direct interaction between Prp28 and the Prp8-NTD has not been reported, we were able to detect binding by GST pull-down using moderately stringent wash conditions (200 mM KOAc at room temperature). However, the prp8-tes substitutions did not alter that interaction under the conditions of our assay (Fig. 2D). These results do not exclude the possibility that the prp8-tes substitutions alter Prp8-Prp28 interactions in a way that alters regulation of Prp28 activity by Prp8. 
A pro28- - prp8-P263LW279G with:

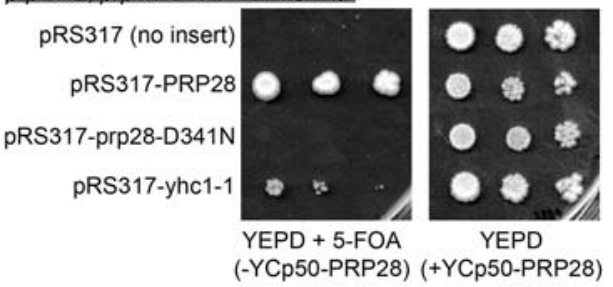

B

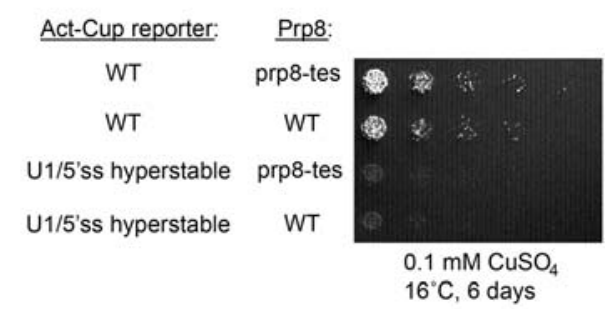

C

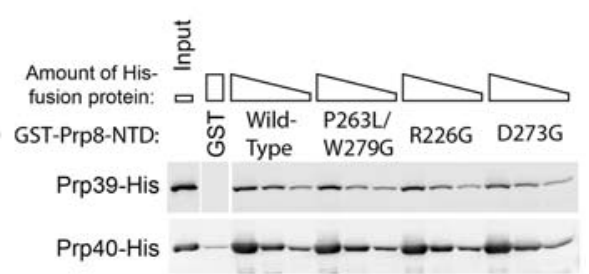

D

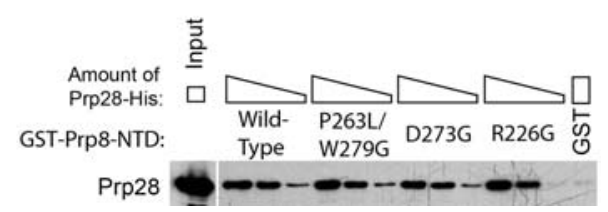

FIGURE 2. prp8-tes does not bypass Prp28, suppress U1/5'ss hyperstabilization, or alter interactions with U1 proteins Prp39 or Prp40 in vitro. (A) prp8-P263L/W279G does not bypass the requirement for Prp28. A prp28A/prp8 8 strain (JG140) containing wild-type PRP28 on a URA3marked plasmid and pRS313-prp8-P263L/W279G was transformed with pRS317 (empty vector), pRS317-PRP28, pRS317-prp28-D341N (should be catalytically inactive), or pRS317-yhc1-1, which is known to bypass Prp28 (Chen et al. 2001). Tenfold serial dilutions were plated on YEPD or YEPD +5 -FOA and grown at $30^{\circ} \mathrm{C}$ for $3 \mathrm{~d}$. Only strains with pRS317-PRP28 or pRS317-yhc1-1 were able to grow in the absence of the URA3-marked PRP28 plasmid. (B) prp8-tes does not suppress U1/ 5'ss hyperstabilization. Fivefold serial dilutions of strains with PRP8 or prp8-P263L/W279G and wild-type or U1/5'ss hyperstabilized ActCup splicing reporters (Staley and Guthrie 1999) were plated onto SD-Ura medium with $0.1 \mathrm{mM}$ copper sulfate, and grown at $16^{\circ} \mathrm{C}$ for $6 \mathrm{~d}$. In the presence of the U1/5'ss hyperstabilized Act1-Cup1 reporter, wild-type PRP8 and prp8-tes strains grow equally poorly at $16^{\circ} \mathrm{C}$ on $0.1 \mathrm{mM}$ copper sulfate. $(C) \operatorname{Prp} 39$ and Prp40 bind similarly to wildtype Prp8-NTD, Prp8-NTD(P263L/W279G), Prp8-NTD(R226G), and Prp8-NTD(D273G). His $_{6}$ fusion Prp39 or Prp40 proteins were added to bead-bound GST-fusion Prp8-NTD proteins in a threefold dilution series. GST-only beads were incubated with the highest amount of His-fusion protein, and Input lanes contain $25 \%$ of the lowest amount of His-fusion protein used in the binding reactions. (D) Prp28 binds similarly to Prp8-NTD and Prp8-NTD-tes alleles. His ${ }_{6}$ fusion Prp28 was added to bead-bound GST-fusion Prp8-NTD proteins in a fourfold dilution series. GST-only beads were incubated with the highest amount of Prp 28 protein, and Input lane contains $65 \%$ of the lowest amount of Prp28 used in the binding reactions.

\section{A prp8-tes allele partially suppresses the prp28-1 global splicing defect}

To measure the effect of a prp8-tes mutation on the global splicing defect caused by prp28-1 in vivo, we used splicingspecific DNA microarrays (Pleiss et al. 2007). The prp8-tes strain $P 263 L / W 279 G$ was chosen for this and subsequent assays, as it displays strong suppression of the prp28-1 growth defect. Cy3- or Cy5-labeled cDNA was made from total cellular RNA isolated from wild-type, prp28-1, prp8-tes, or prp281/prp8-tes double-mutant strains, then was competitively hybridized to DNA microarrays as indicated in Figure 3.

Genome-wide splicing improved in the prp28-1/prp8-tes strain relative to prp28-1 alone. The prp28-1 strain exhibited a broad splicing defect at $16^{\circ} \mathrm{C}$, characterized by increases in intron levels and decreases in spliced RNA levels relative to wild-type, consistent with our previous report (Fig. 3, lanes 6,10; Pleiss et al. 2007). The prp8-tes strain by itself behaved similarly to wild type (lanes $1,5,9$ ), as expected given its lack of growth defect. Suppression of the prp28-1 splicing defect can be seen by comparing the prp28-1 versus wild-type pattern to the prp28-1/prp8-tes versus wild-type pattern (cf. lanes 6 and 7), or by directly testing suppression on the array by competitively hybridizing cDNA from prp28-1 against cDNA from prp28-1/prp8-tes (lanes 4,8,12). Intron-containing RNA accumulated to some extent in the suppressed double mutant relative to wild type (lane 7). A mild level of suppression is consistent with the incomplete suppression of the prp28-1 growth defect (Fig. 1B).

\section{U2 snRNP joining and subsequent steps of spliceosome assembly are inhibited by prp28-1 in vivo}

In order to determine the precise defect in the prp28-1 strain that is suppressed by prp8-P263L/W279G, we monitored the kinetics of cotranscriptional spliceosome assembly in prp28-1 and prp28-1/prp8-tes strains using chromatin immunoprecipitation (ChIP). We measured the occupancy of several HA-tagged splicing factors (representatives of the U1, U2, and U5 snRNPs and of the NTC) at five positions along an intron-containing gene, ECM33. As pre-mRNA is synthesized, splicing factors bind and can be cross-linked to nearby DNA. Thus, the position of cross-linking along a gene can be used as a readout for splicing factor association with the nascent pre-mRNA (Fig. 4A; Kotovic et al. 2003; Görnemann et al. 2005; Lacadie and Rosbash 2005). To compare spliceosome assembly at permissive and nonpermissive temperatures, cultures were grown at $30^{\circ} \mathrm{C}$, then divided and incubated at either $30^{\circ} \mathrm{C}$ or $16^{\circ} \mathrm{C}$ for $45 \mathrm{~min}$.

Our results for a wild-type strain at $30^{\circ} \mathrm{C}$ are consistent with previous reports (Görnemann et al. 2005; Lacadie and Rosbash 2005). U1 snRNP association peaked near the region of ECM33 DNA that corresponds to the 3'ss, then decreased by $500 \mathrm{bp}$ downstream to a level similar to that at the $5^{\prime} \mathrm{ss}$, 


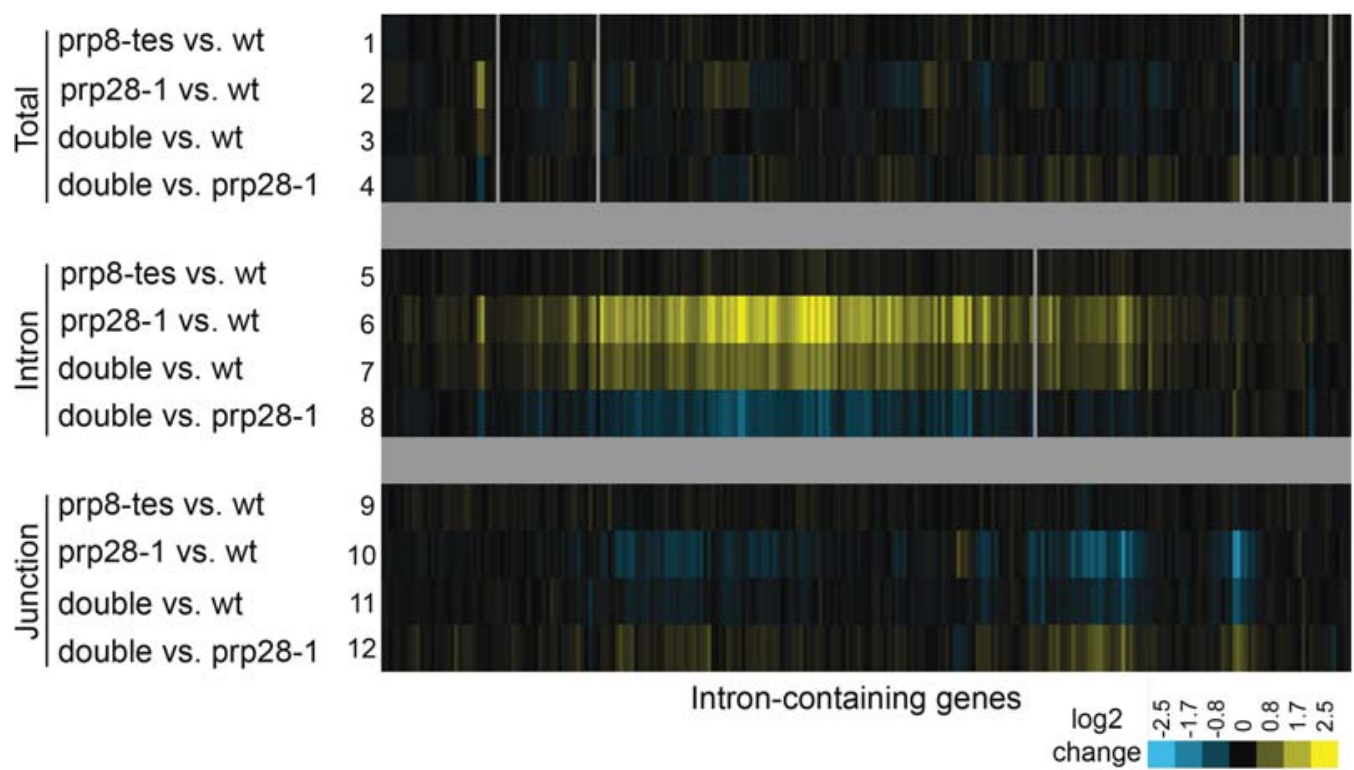

FIGURE 3. The global splicing defect of the prp28-1 mutant is partially suppressed by prp8-P263L/W279G. Each of 253 introns is represented by three probes on a DNA microarray (Pleiss et al. 2007): one in an exon to detect total RNA (lanes 1-4), one in the intron to detect unspliced pre-mRNA (lanes 5-8), and one across the exon-exon junction to detect spliced mRNA (lanes 9-12). Differentially labeled cDNA samples from pairs of strains were competitively hybridized to each array and $\log 2$-transformed normalized fluorescence ratios are presented. Yellow indicates an increase (ratio $>0$ $[\log 2])$ and blue a decrease $($ ratio $<0[\log 2])$ in signal. (Lanes 1,5,9) prp8-P263L/W279G hybridized against wild-type; (lanes 2,6,10) prp28-1 against wild type; (lanes 3,7,11) prp28-1 + prp8-P263L/W279G ("double") against wild type; (lanes 4,8,12) prp28-1 + prp8-P263L/W279G against prp28-1 to directly measure suppression. Results presented are the average of two biological replicates, each with a dye-flip technical replicate.

consistent with release of the U1 snRNP upon activation of the spliceosome (Fig. 4B, black). U2 snRNP occupancy was highest near the $3^{\prime}$ ss, then slowly decreased over the next 1000 bp (Fig. 4C). U5 and NTC associations were similar: they peaked over the second exon, consistent with trisnRNP and NTC addition following U2 snRNP binding (Fig. 4D,E). When wild-type cultures were shifted to $16^{\circ} \mathrm{C}$ prior to cross-linking for ChIP, the patterns of U1 snRNP and NTC binding were similar to those at $30^{\circ} \mathrm{C}$ (Supplemental Fig. 1). U2 and U5 snRNP associations were slightly delayed compared with $30^{\circ} \mathrm{C}$, but reached similar maximum levels (Supplemental Fig. 1).

The prp28-1 strain shifted to restrictive temperature $\left(16^{\circ} \mathrm{C}\right)$ yielded a dramatically different ChIP pattern (Fig. $4 \mathrm{~B}-\mathrm{E}$, orange). In agreement with the function of Prp28 in displacing the U1 snRNP from the 5 'ss, we observed persistence of the U1 snRNP signal in the prp28-1 background up to $1500 \mathrm{bp}$ downstream from the $5^{\prime}$ ss (Fig. 4B). This delayed release was most pronounced at $16^{\circ} \mathrm{C}$, but was evident even at permissive temperature $\left(30^{\circ} \mathrm{C}\right)$. U2 snRNP recruitment was predicted to be unaltered by the prp28-1 mutation because the U2 snRNP is thought to bind the branch point well before Prp28 removes the U1 snRNP from the 5'ss (for review, see Will and Lührmann 2011). Surprisingly, shifting the prp28-1 strain to $16^{\circ} \mathrm{C}$ caused a pronounced delay in U2 snRNP recruitment and decreased the maximum U2 snRNP signal (Fig. 4C). We also observed a severe delay in U5 snRNP binding at $16^{\circ} \mathrm{C}$ : the highest signal was at the end of the gene and was well below the peak signal observed at $30^{\circ} \mathrm{C}$ (Fig. 4D). This finding was confirmed by analyzing the U5 snRNP pattern along SEC27, a gene with a longer second exon than ECM33 (Supplemental Fig. 2). We conclude that prp28-1 causes a delay in recruitment of the U2 and tri-snRNPs to introns in vivo.

The prp28-1 strain exhibited even more dramatically delayed/reduced association of NTC, even at permissive temperature (Fig. 4E). The NTC joins the spliceosome soon after the tri-snRNP (Hoskins et al. 2011) and appears to be more stably associated after the U4 snRNP is released from the tri-snRNP (Fabrizio et al. 2009). Thus, the result that the NTC is even more sensitive to prp28-1 is consistent with the allosteric cascade model, which posits that later binding events are dependent on conformational changes induced by earlier binding events (Brow 2002). Similarly, the inhibition of U2 snRNP joining by prp28-1 may be a consequence of decreased commitment complex 2 formation (see below).

The prp8-tes allele partially suppressed all of the cotranscriptional assembly defects caused by prp28-1 at the nonpermissive temperature. U1 snRNP release was still somewhat delayed in the prp28-1/prp8-tes strain, but substantially less so than in the absence of the suppressor mutation (Fig. $4 \mathrm{~B})$. A corresponding increase in the rate and magnitude of recruitment of U2 snRNP, U5 snRNP, and NTC was observed at $16^{\circ} \mathrm{C}$ (Fig. 4C-E). The ability of prp8-tes to suppress the $\mathrm{U} 2$ association defect suggests that Prp8, a component of 
Price et al.

A
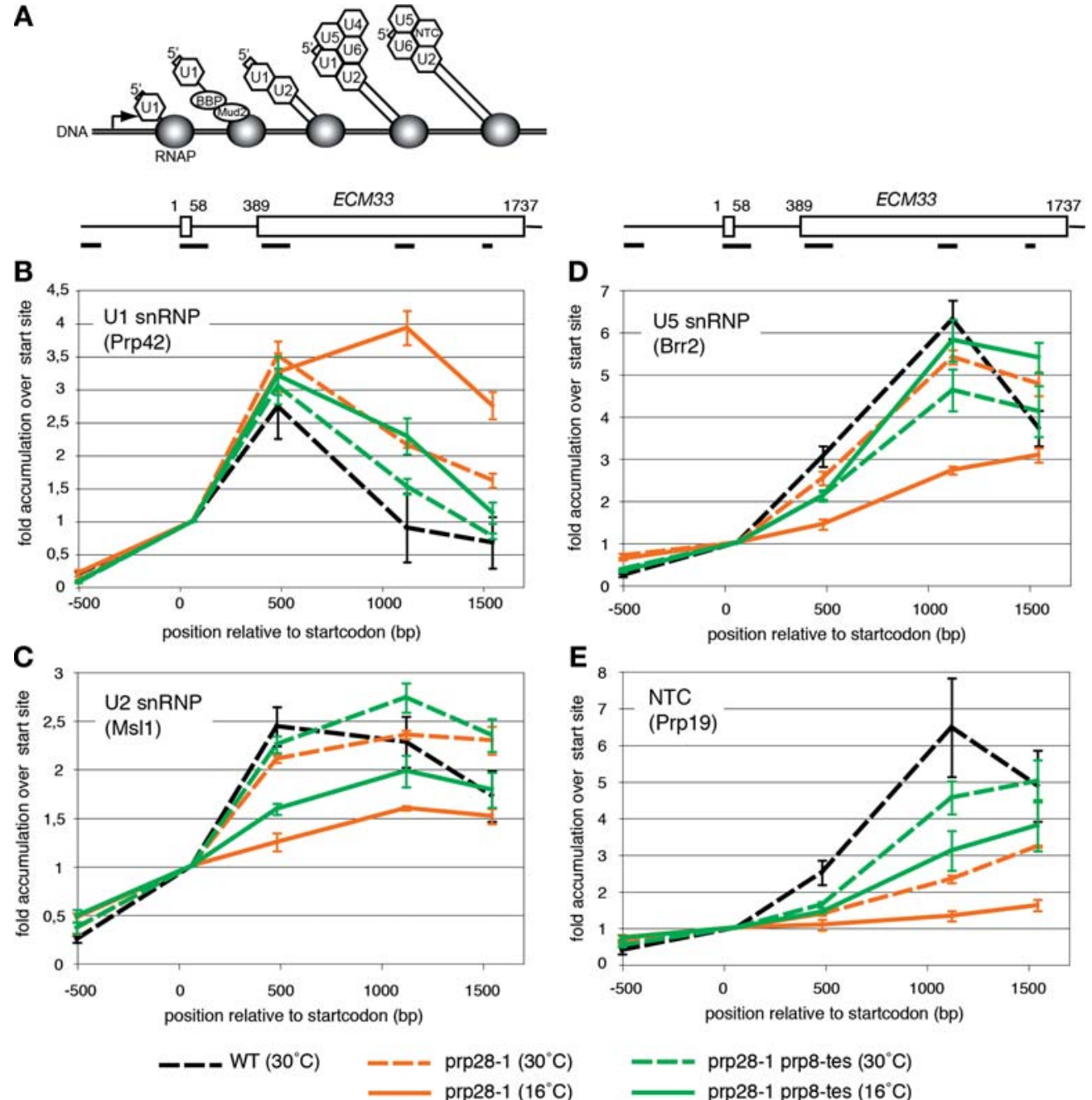

FIGURE 4. The prp28-1 mutation delays cotranscriptional spliceosome assembly at the ECM33 gene. (A) Diagram of the expected order of snRNP and NTC occupancy of nascent transcripts along the ECM33 gene. The short and long open rectangles represent the $5^{\prime}$ and $3^{\prime}$ exons, respectively. (RNAP) RNA polymerase II. In order, from the transcription start site (bent arrow), the splicing complexes are as follows: CC1, CC2, pre-spliceosome, complete spliceosome, and active spliceosome. $(B-E)$ Data for four HA-tagged splicing factors, which are components of three snRNPs and the NineTeen Complex (NTC), as indicated on each panel. Diagrams at top show the positions of qPCR amplicons used for ChIP analysis of the gene ECM33. In the panels aligned below, data points are placed according to the positions of the PCR products along the gene. Cross-linking of each factor was assessed in strains with wild-type PRP28 and PRP8 (black line), prp28-1 and wild-type PRP8 (orange lines), and prp28-1 and prp8-P263L/W279G (green lines). Strains were grown at $30^{\circ} \mathrm{C}$ (dashed lines) or $16^{\circ} \mathrm{C}$ (solid lines). The data represent the average of at least three independent experiments. Error bars, SEM.

the tri-snRNP, can influence a step of splicing that occurs prior to tri-snRNP incorporation into the spliceosome.

\section{U2 and tri-snRNP association are inhibited by prp28-1 in vitro, and inhibition is suppressed by prp8-tes}

To determine whether the effects of prp28-1 and prp8-tes on U2 snRNP and U5 snRNP association also occur in the absence of chromatin and transcription, we monitored the kinetics of spliceosome assembly in vitro at $16^{\circ} \mathrm{C}$ (Fig. 5). snRNP association with biotinylated pre-mRNA as a function of time was determined by streptavidin affinity purification, followed by RT-qPCR for each snRNA. All five snRNPs asso- ciated rapidly with pre-mRNA in wild-type splicing reactions, reaching maximum accumulation at $5-15 \mathrm{~min}$. Using a pull-down procedure with low stringency washes to maintain U1 snRNP association, we were able to see that prp28-1 blocks release of U1 snRNP in vitro (Fig. 5A) as proposed, but not directly observed previously (Staley and Guthrie 1999). At most time points, about twofold more U1 was pulled down from reactions containing prp28-1 extract than from reactions containing wild-type extract (Fig. 5A). We also confirmed the previous report that U4 is released in wild-type reactions, but retained in prp28-1 reactions at late time points (Fig. 5B; Staley and Guthrie 1999). Consistent with our in vivo ChIP results, we found that association 

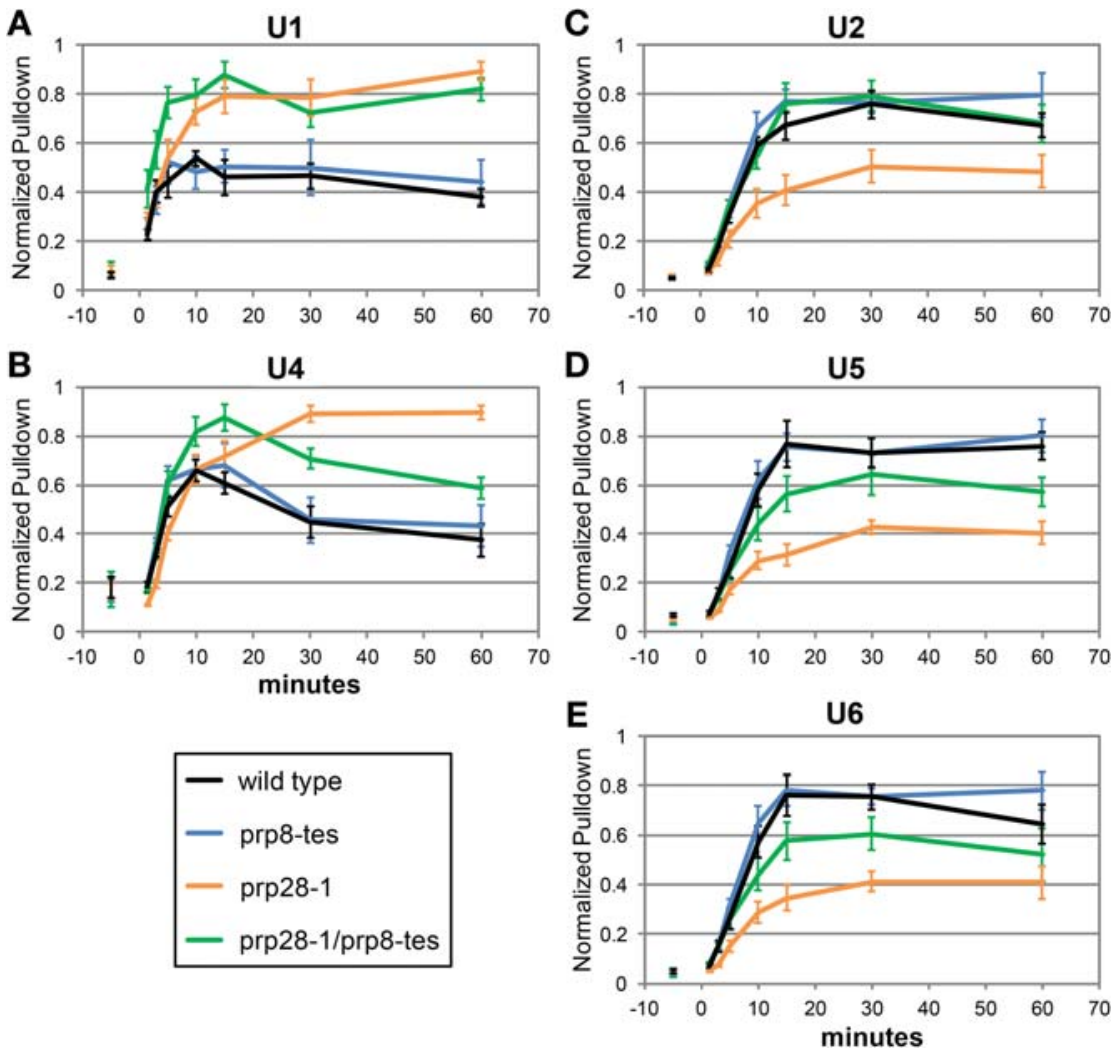

FIGURE 5. In vitro, prp28-1 blocks U1 and U4 release and reduces stable U2, U5, and U6 association. Splicing extracts made from four strains (wild type: black, prp28-1: orange, prp8-P263L/ W279G: blue, prp28-1 + prp8-P263L/W279G: green lines) were incubated with biotinylated actin pre-mRNA at $16^{\circ} \mathrm{C}$. Aliquots were taken at the indicated times and snRNAs bound to the premRNA were detected by RT-qPCR. (A-E) Pull-down results for U1, U4, U2, U5, and U6 snRNAs, respectively. Reactions with the four extracts were performed in parallel. The " -5 min" time point represents background (mock pull-down without pre-mRNA). The data were normalized as described in Materials and Methods. Error, SEM after normalization.

of U2, as well as U5 and U6, was inhibited in reactions containing prp28-1 relative to wild type (Fig. 5C-E). The accumulation of excess U4 RNA in spliceosomes assembled in prp28-1 extract, despite the decreased level of U5 and U6 RNAs, implies that decreased tri-snRNP recruitment is accompanied by decreased Brr2 activity, and thus increased U4 snRNP retention as observed previously (Staley and Guthrie 1999). Our in vivo and in vitro results suggest that Prp28 has at least two functions: one important for early spliceosome assembly, affecting U2 and subsequent tri-snRNP association with pre-mRNA, and one required for U1 and U4 release after spliceosome assembly.

The prp8-tes allele was able to suppress most of the in vitro spliceosome assembly defects (Fig. 5A-E, green). Importantly, the reduction in U2 snRNA pull-down was completely suppressed, which indicates that the functional role of Prp8 early in spliceosome assembly is not specific to cotranscriptional spliceosome assembly. The defects in U5 and U6 binding and U4 release were also partially suppressed. However, U1 release was not improved in the prp28-1/prp8-tes double-mutant extract (see Discussion).

\section{prp28-1 inhibits ATP-independent CC2 formation}

The surprising in vivo and in vitro defect in U2 snRNP recruitment caused by prp28-1 could result from inhibition of an even earlier assembly step, so we investigated commitment complex and prespliceosome formation directly. Splicing reactions with radiolabled RP51A pre-mRNA were incubated at nonpermissive temperature $\left(16^{\circ} \mathrm{C}\right)$ and run on native gels that resolve CC1 from CC2 (Seraphin and Rosbash 1989, 1991). Wild-type splicing reactions depleted of ATP formed roughly equal amounts of $\mathrm{CC} 1$ and $\mathrm{CC} 2$, and very little pre-spliceosome or spliceosome (P/SP; these complexes comigrate) (Fig. 6, lane 1). Addition of ATP and incubation for an additional 20 min converted most of the CC2 into P/SP (Fig. 6, lane 5). In contrast, prp28-1 splicing reactions without ATP accumulated the majority of premRNA in CC1 (Fig. 6, lane 3), and the CC1 band appeared more diffuse. Upon addition of ATP to the prp28-1 splicing reaction, only about half as much premRNA was converted to P/SP than was with wild-type extract, and most of the pre-mRNA that remained in commitment complexes remained in CC1 (Fig. 6, lane 7). Thus, prp28-1 not only inhibits U2 snRNP joining but also reduces BBP and Mud2 association with CC1 (see Fig. 4A). The decrease in U2 joining, seen in this assay and in Figures 4 and 5, is thus likely a downstream result of inefficient CC2 formation.

Splicing is not completely blocked at $16^{\circ} \mathrm{C}$ by the prp28-1 mutation (Strauss and Guthrie 1991; data not shown), so we repeated the commitment complex gels with extracts from a strain in which Prp28 expression can be turned off by growth in glucose-containing media (P Raghunathan and C Guthrie, unpubl.). After 3.5-5 h of growth in the presence of glucose, splicing extract made from these cells no longer contained HA-tagged Prp28 detectable by Western blot for HA and failed to splice at $16^{\circ} \mathrm{C}$ (data not shown). This extract formed even less CC2 (-ATP) and subsequent splicing complexes (+ATP) than prp28-1 extract (Fig. 6, lanes 9-10). This result confirms that Prp28 contributes to the ATP-independent formation of CC2, and shows that the defect in CC2 formation is not specific to the prp28-1 allele.

We also assayed the ability of prp8-tes to suppress the prp28-1 defects in CC2 and pre-spliceosome formation (Fig. 6, lanes 4,8). Only partial suppression was observed, but prp8-tes/prp28-1 extract reproducibly formed CC2 and 


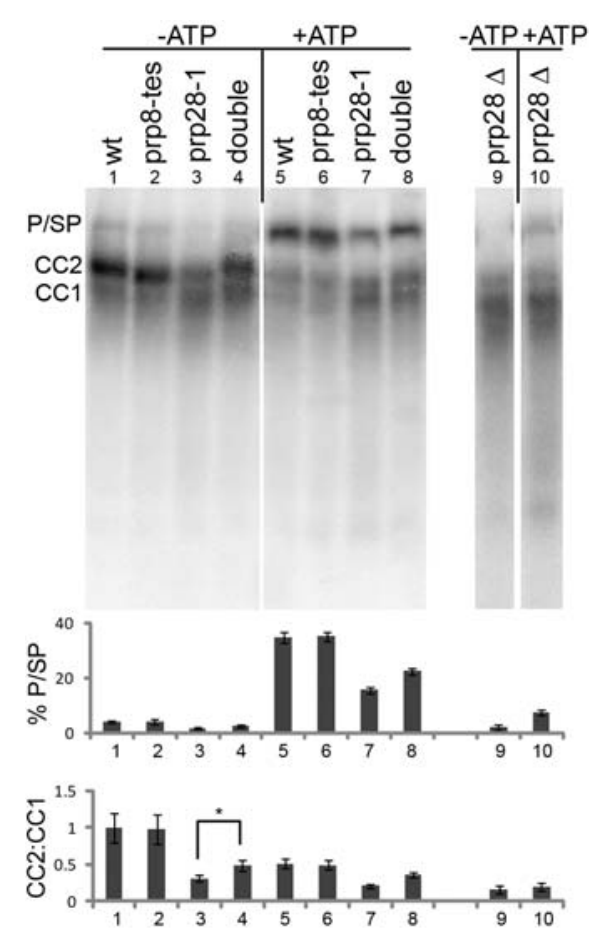

FIGURE 6. $\operatorname{prp} 28-1$ inhibits formation of CC2 and the transition from commitment complex to pre-spliceosome. Complexes assembled on ${ }^{32} \mathrm{P}$-labeled RP51A pre-mRNA substrate in the presence or absence of ATP were resolved on a nondenaturing acrylamide/agarose composite gel. (Lanes 1-4,9) no ATP added; (lanes 5-8,10) 2 mM ATP added. (Lanes 1,5) wild-type extract; (lanes 2,6) prp8-P263L/W279G extract; (lanes 3,7) prp28-1 extract; (lanes 4,8) prp28-1 + prp8-P263L/W279G extract; (lanes 9,10) extract from cells genetically depleted of Prp28. (CC1) Commitment complex 1; (CC2) commitment complex 2; (P/ $\mathrm{SP})$ pre-spliceosome/spliceosome, which comigrate on these gels. Percentage of substrate in $\mathrm{P} / \mathrm{SP}$ band, relative to the sum of $\mathrm{P} / \mathrm{SP}$, $\mathrm{CC} 1$, and CC2 bands, and ratio of CC2:CC1 are presented below. Error, SEM. (*) Paired $t$-test conducted, pairing samples run on the same gel: significantly different, $P=0.00023$.

pre-spliceosome better than PRP8/prp28-1 extract. Therefore, Prp8, in addition to Prp28, influences this ATP-independent step of spliceosome assembly.

\section{DISCUSSION}

\section{A novel, ATP-independent function of Prp28 in CC2 formation}

Here we have shown that the DEAD-box ATPase Prp28 has an unanticipated function early in spliceosome assembly. Specifically, we found that $\operatorname{Prp} 28$ promotes formation of CC2 prior to the first ATP-dependent step of splicing, since ATP-depleted splicing reactions containing prp28-1 or depleted of Prp28 accumulated CC1 instead of CC2 (Fig. 6). We also observed prp28-1-dependent decreases in U2 and tri-snRNP association in vitro and in vivo, which are likely downstream effects of the failure to efficiently or stably form CC2 (Figs. 4, 5). Previous studies on Prp28 indicated that it acts during spliceosome activation to promote $\mathrm{U} 1$ snRNP release (Staley and Guthrie 1999; Chen et al. 2001; Ismaili et al. 2001), and our current results confirm this conclusion. Therefore, we propose a model in which Prp28 has at least two roles during spliceosome assembly and activation: one ATP-independent role in which Prp28 helps stabilize U1, BBP, and Mud2 on the pre-mRNA during CC2 formation, and a subsequent ATP-dependent role in which Prp28 facilitates the release of U1 following tri-snRNP association (Fig. 7).

Prp28 is an essential gene, but becomes nonessential in the presence of mutations predicted to destabilize the U1/5'ss interaction and facilitate U1 release independent of Prp28 (Chen et al. 2001; Hage et al. 2009; Schwer et al. 2013). Therefore, while Prp28 strongly stimulates CC2 formation on the gene we tested, it is likely not absolutely required for this assembly step. Indeed, cells that have lost PRP28 in the presence of the $y$ hcl-1 bypass mutant grow very slowly (Fig. 2B), consistent with the low level of CC2 formation that we observed in extract depleted of Prp28 (Fig. 6).

It is not surprising that a substitution in a conserved helicase motif of Prp28 inhibits its ATP-dependent function in U1 snRNP displacement, but why would this substitution affect an ATP-independent role in CC2 formation? Motif $\mathrm{Ib}$, in which the prp28-1 substitution lies, is implicated in RNA binding (Fairman-Williams et al. 2010), and so may

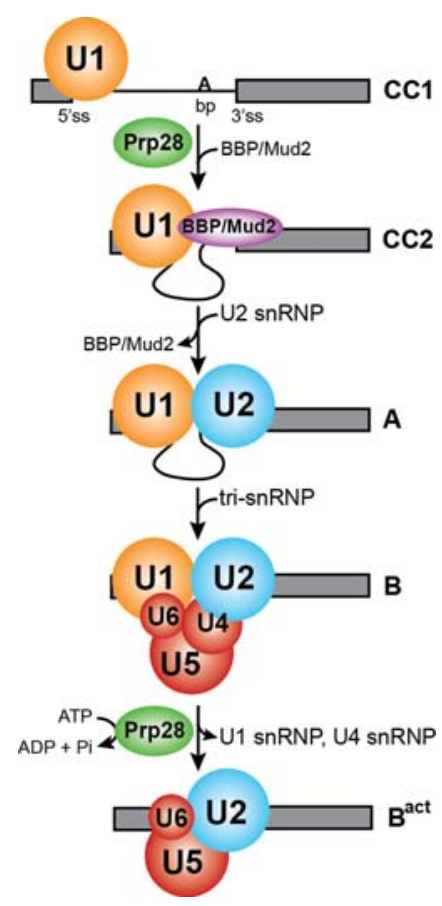

FIGURE 7. Model for the dual functions of Prp28 in spliceosome assembly and activation. Prp28 has an early, ATP-independent function in assembly of commitment complex 2 (CC2) and the pre-spliceosome (A), as well as a later, ATP-dependent function in conversion of the complete spliceosome (B) into the active spliceosome $\left(\mathrm{B}^{\text {act }}\right)$. Only selected splicing factors are shown. 
influence the ATP-independent interaction with an RNA substrate.

The DExD/H-box splicing factors Prp5 and Sub2 also have both ATP-dependent and ATP-independent roles in spliceosome assembly. Prp5 uses ATP hydrolysis to promote rearrangements in the U2 snRNP that allow U2 RNA to basepair with the branchsite, but it first helps recruit U2 to the pre-mRNA in an ATP-independent manner (Perriman et al. 2003; Xu et al. 2004; Kosowski et al. 2009). In addition, extracts depleted of Prp5 are less able to form commitment complexes (Kosowski et al. 2009). Sub2 uses ATP hydrolysis to release BBP and Mud2 during pre-spliceosome formation (Kistler and Guthrie 2001; Libri et al. 2001), but is also required for CC2 formation: Depletion of Sub2 results in spliceosomes that are stalled at CC1 (Zhang and Green 2001). Our finding that Prp28 promotes CC2 formation suggests that Prp28, Sub2, and Prp5 all collaborate to promote formation of $\mathrm{CC} 2$, whose components they later destabilize.

\section{Substitutions in the U5 snRNP protein Prp8 promote formation of early spliceosomal complexes}

Our finding that substitutions in the $\mathrm{N}$ terminus of Prp8, an integral U5 snRNP and tri-snRNP protein, suppress the early assembly defects caused by prp28-1, supports the hypothesis that the U5 snRNP functions in the earliest steps of spliceosome assembly, prior to its stable incorporation into the spliceosome. We identified 15 "prp8-tes" substitutions spanning a recently proposed bromodomain in the $\mathrm{N}$ terminus of Prp8, each of which partially suppressed the cold-sensitive growth defect of a prp28-1 strain. We tested one of the strongest prp8-tes alleles in subsequent assays, and it was able to partially suppress every prp28-1 splicing defect discussed above, including the CC2 and pre-spliceosome formation defects (Figs. 4-6), except the in vitro U1 snRNP release defect (Fig. 5A). Suppression of the U1 snRNP release defect could be substrate dependent, or could require that additional factors specific to cotranscriptional splicing collaborate with Prp8 and Prp28 to promote U1 release in vivo. The strongest prp8-tes allele did not bypass the growth requirement for Prp28, nor did it physically interact differently with two U1 snRNP proteins or suppress the growth defect caused by hyperstabilizing U1/5'ss base-pairing (Fig. 2). Together, our results indicate that prp8-tes suppresses prp28-1 by promoting formation of early splicing complexes, not by destabilizing $\mathrm{U} 1$ from the spliceosome.

The finding that substitutions in Prp8 suppress the earliest spliceosome assembly defects caused by prp28-1 raises the intriguing possibility that both Prp28 and Prp8 act on CC1 in the context of the U5 snRNP. Yeast Prp28 is associated only weakly with U5 snRNP (Gottschalk et al. 1999; Stevens et al. 2001; Small et al. 2006) and our results do not determine whether it promotes CC2 formation as a component of the U5 snRNP or tri-snRNP, or as a free protein. Prp8, however, is an integral component of both the U5 snRNP and tri-snRNP and is unlikely to exist as free protein, so it presumably acts as part of the U5 snRNP or tri-snRNP when influencing CC2 formation. Whether the U5 snRNP or the tri-snRNP interact with the pre-mRNA early in spliceosome assembly has been a controversial topic in the splicing field. Several prior observations are consistent with an early, transient role for Prp8 and the U5 snRNP. In vitro cross-linking data place the U5 snRNA and Prp8 at the 5'ss at early timepoints in the splicing cycle, both in human (Wassarman and Steitz 1992; Wyatt et al. 1992; Ast and Weiner 1997) and yeast (Newman et al. 1995) cell extracts. Also, affinity-purified human pre-spliceosomes contain U5 snRNP proteins, including Prp28 (Hartmuth et al. 2002). Further characterization of an early interaction between Prp8 and the $5^{\prime}$ ss showed that it required intact U4 and U6 RNAs and ATP, but was independent of U2 snRNP binding to the branch point (Maroney et al. 2000). Therefore, trisnRNP/pre-mRNA interactions apparently occur prior to U2 binding. However, more recent ChIP and single-molecule studies found that in wild-type yeast cells or yeast cell extract, spliceosome assembly usually takes place in a stepwise sequence according to the canonical assembly pathway (Kotovic et al. 2003; Görnemann et al. 2005; Lacadie and Rosbash 2005; Lacadie et al. 2006; Hoskins et al. 2011). These latter studies showed that the spliceosome is unlikely to bind an intron as a pre-formed penta-snRNP, but they do not rule out the transient U5-U1-pre-mRNA interactions that are suggested by our results and others.

While our results implicate the U5 snRNP in early spliceosome assembly events, we cannot rule out the possibility that Prp 28 promotes CC2 formation as a free protein and the prp8-tes substitutions destabilize Prp28-U5 snRNP interactions, thereby increasing the pool of free Prp28 and compensating for reduced Prp28 function. We found that the N-terminal domain of Prp8 binds Prp28 in vitro, and the prp8-tes alleles do not alter the pull-down of $\operatorname{Prp} 28$ with Prp8-NTD (Fig. 2D). However, prp8-tes alleles could interact differently with Prp28 in the context of full-length Prp8 and the U5 snRNP. Alternatively, the prp8-tes mutations may alter interactions in the Aar2-U5 snRNP, which is a precursor of the U5 snRNP that lacks Brr2 and copurifies with the U1 snRNP (Gottschalk et al. 2001; Weber et al. 2011). If the U1 snRNP's interaction with the Aar2-U5 snRNP competes with stable CC2 formation, weakening this interaction via substitutions in Prp8 could promote CC2 formation.

\section{Prp8 as a master regulator of spliceosome assembly}

Prp8 sits at the heart of the spliceosome starting from the time the tri-snRNP binds until after the second step of catalysis, has an extensive set of physical and genetic interactions with other spliceosome components, and has been shown to regulate Brr2 for U4/U6 unwinding (Maeder et al. 2008; MozaffariJovin et al. 2012, 2013). Because of these many interactions, Prp8 is perfectly situated to be a master regulator of 
spliceosome assembly, activation, and disassembly. Here, we have shown that substitutions in the $\mathrm{N}$ terminus of Prp8 promote CC2 and pre-spliceosome formation in a prp28-1 background. Thus, Prp8 may also regulate the earliest steps of spliceosome assembly, even before stable tri-snRNP joining. This regulation could be through physical contacts that Prp8 makes with U1 snRNP proteins or the U1 snRNA ( $\mathrm{Li}$ et al. 2013), although the Prp8/U1 protein interactions tested here were not affected by prp8-tes alleles (Fig. 2). Prp8 may also exert its influence on this step by regulating the activity of Prp28; for example, by switching Prp28 between two states: one that promotes a U1 conformation that is favorable for CC2 formation, and one in which Prp28's ATPase activity is activated to promote U1 release after tri-snRNP joining. Additional structural and biochemical studies will be required to discriminate between such possibilities.

\section{MATERIALS AND METHODS}

\section{Yeast strains}

Yeast strains used in this study are listed in Supplemental Table 1. For strains JG111-JG116 and JG121-JG126, a C-terminal $\mathrm{HA}_{6}$ tag was added to splicing factors by one-step gene replacement using K. lactis TRP1 as a selection marker (Knop et al. 1999). Wild-type strains for ChIP are as described (Görnemann et al. 2011). Strains JG110/AMP27 and JG120/AMP28 were generated by replacing YCp50-PRP8 in ANK828 with pRS313-PRP8 (Kuhn and Brow 2000) or pRS313-prp8-P263L/W279G by plasmid shuffle. AMP25 and AMP26 were generated by crossing ANK828 to EJS54 (a gift from E. Strauss: wild-type sister spore of the parent strain of ANK828, EJS51) (Strauss and Guthrie 1991) and selecting for prp84::ADE2 PRP28 spores, then replacing YCp50-PRP8 with pRS313-PRP8 or pRS313-prp8-P263L/W279G by plasmid shuffle.

\section{Selection for suppressors of prp28-1 in PRP8}

We used error-prone PCR and gap repair as described previously (Umen and Guthrie 1996) to introduce mutations into the first quarter of the PRP8 gene. A region of pRS313-PRP8 including $233 \mathrm{bp}$ of vector sequence as well as $719 \mathrm{bp}$ upstream of the PRP open reading frame and the first $1980 \mathrm{bp}$ of the open reading frame were amplified with Taq DNA polymerase and cotransformed into ANK828 with pRS313-PRP8 that was gapped by restriction digest with XhoI and SalI between base pairs $(-717)$ and base pairs 1715 relative to the start codon. Functional PRP8 alleles were selected by their ability to lose the wild-type copy of PRP 8 on medium containing 5-FOA, then suppressors of prp28-1 were selected by replica plating to YEPD and incubating at $16^{\circ} \mathrm{C}$. Colonies present after $14 \mathrm{~d}$ were transferred to fresh medium. Plasmids were isolated from clones that had grown at $16^{\circ} \mathrm{C}$ within $10 \mathrm{~d}$, their suppression capacity confirmed by retransforming ANK828, and then sequenced from 50 bp upstream of the Prp8 open reading frame to codon 660 to identify mutated residues. Three independent selections were performed. The ApaI/SalI fragments (base pairs -726 to +1715 ) were subcloned into pRS313-PRP8 to ensure that suppression was due to mutations within this region. Selected mutations from clones with more than one amino acid substitution were introduced into
pRS313-PRP8 as single substitutions using the QuikChange technique (Stratagene) and analyzed for their ability to suppress the cold-sensitivity of prp28-1. All suppressor alleles were also introduced into ANK800 (wild type), ZRL102 (U4-cs1), and ANK821 (brr2-1), and the wild-type allele of PRP8 was shuffled out to test for genetic interactions. Growth at different temperatures was assayed by spotting 10 -fold serial dilutions of $\mathrm{OD}_{600}=0.25$ cultures on solid YEPD medium, followed by incubation as indicated.

\section{Test for bypass suppression of prp28-1}

Strain JG140 was constructed by one-step gene disruption of the PRP28 locus in strain JG120, using the PCR-amplified kanMX6 cassette of pYM1 (Knop et al. 1999) adding 45-bp homologous overhangs to delete base pairs -2 to +1650 of the PRP28 locus. The PCR product was cotransformed with YCp50-PRP28. Resulting strains were transformed with pRS317-PRP28, pRS317-prp28D341N, or pRS317-yhc1-1 to create strains JG141, JG142, and JG144. Tenfold serial dilutions of $\mathrm{OD}_{600}=0.25$ cultures were then plated onto YEPD or YEPD + 5-FOA to select for loss of YCp50PRP28, and grown at $30^{\circ} \mathrm{C}$.

\section{Test for suppression of $\mathrm{U} 1 / \mathbf{5}^{\prime}$ ss hyperstabilization}

A prp84::LYS2 strain, TB72 (a gift from T. Brenner), was crossed to a cup1 1 ::ura3-52 strain, YS72 (Burgess and Guthrie 1993), and a prp84, cup1 $1 \Delta$ spore was selected. This strain, AMP24, was transformed with pRS313-PRP8 or pRS313-prp8-P263L/W279G, and with Act1-Cup1 splicing reporters (Lesser and Guthrie 1993) pCG90 (wild type) or pCG91 (5'ss modified to extend U1/5'ss base-pairing to $10 \mathrm{bp}$ ) (Staley and Guthrie 1999), generating AMP39-42. Cultures were grown to $\mathrm{OD}_{600} 0.6$, diluted back to $\mathrm{OD}_{600} 0.1$, and fivefold serial dilutions were plated onto SD -Ura medium with varying concentrations of copper and were grown for $6 \mathrm{~d}$ at $16^{\circ} \mathrm{C}$.

\section{GST pull-down assay to test in vitro protein-protein interactions}

Prp28 protein was expressed in E. coli BL21(DE3) RIPL (Agilent) from plasmid pRSetA-Prp28 (a gift from Nils Walter), in which Prp28 has a C-terminal His 6 tag. Three liters of bacteria containing the Prp28 plasmid were grown to $\mathrm{OD}_{600} 0.6$ and induced with 1 $\mathrm{mM}$ IPTG at $18^{\circ} \mathrm{C}$ for $15 \mathrm{~h}$. Cells were harvested and frozen at $-80^{\circ} \mathrm{C}$. Cells were then resuspended in $50 \mathrm{mM} \mathrm{NaH}_{2} \mathrm{PO}_{4}(\mathrm{pH} \mathrm{8.0)}$, $300 \mathrm{mM} \mathrm{NaCl}, 5 \mathrm{mM} \beta$-mercaptoethanol, $10 \mathrm{mM}$ imidazole, and sonicated in five 30 -sec bursts at $10 \%$ intensity with 30 -sec rests. Lysate was clarified for $30 \mathrm{~min}$ at 20,000 RPM in a JA25.5 rotor, then the supernatant was passed through a $0.22-\mu \mathrm{M}$ filter and flowed over a column of Ni-NTA Agarose (Qiagen). Beads were washed with $50 \mathrm{mM} \mathrm{NaH}_{2} \mathrm{PO}_{4}, 300 \mathrm{mM} \mathrm{NaCl}, 5 \mathrm{mM} \beta$-mercaptoethanol, and 20 $\mathrm{mM}$ imidazole ( $\mathrm{pH} 8$ ), then a second wash with imidazole increased to $36 \mathrm{mM}$. Prp28 protein was eluted with $50 \mathrm{mM} \mathrm{NaH}_{2} \mathrm{PO}_{4}, 300 \mathrm{mM}$ $\mathrm{NaCl}, 5 \mathrm{mM} \beta$-mercaptoethanol, and $250 \mathrm{mM}$ imidazole ( $\mathrm{pH} 8.0$ ), then dialyzed into $20 \%$ glycerol, $100 \mathrm{mM} \mathrm{KCl}, 20 \mathrm{mM}$ HEPES (pH 7.9), $0.2 \mathrm{mM}$ EDTA, $0.5 \mathrm{mM}$ DTT, and stored at $-80^{\circ} \mathrm{C}$.

Full-length Prp39 and Prp40 were tagged with $\mathrm{His}_{6}$ by cloning into pET21b (Novagen) at the BamHI and Xhol restriction sites. Prp39 and Prp40 proteins were expressed in E. coli Rosetta strain 
(Novagen) by growing 100-mL LB cultures to $\mathrm{OD}_{600} 0.8$ and then inducing with $400 \mu \mathrm{M}$ IPTG for $3 \mathrm{~h}$ at $30^{\circ} \mathrm{C}$. Cells were harvested, washed once with $1 \mathrm{x}$ PBS ( $\mathrm{pH} 7.2$ ), resuspended in $1.5 \mathrm{~mL}$ lysis buffer (according to Qiagen protocol for native conditions), and frozen at $-20^{\circ} \mathrm{C}$. After thawing, lysozyme was added to $1 \mathrm{mg} / \mathrm{mL}$ and cells were sonicated in two 15 -sec bursts at $25 \%$ intensity, with a 30-sec break. His $_{6}$-fusion Prp39 and Prp40 were batch purified with Ni-NTA Agarose (Qiagen), following the manufacturer's protocol for native conditions, and stored at $4^{\circ} \mathrm{C}$.

Prp8-NTD (1-330) was GST tagged by cloning into pGEX-KG (Guan and Dixon 1991) at the XmaI and Xhol restriction sites. GST-Prp8-NTD was expressed as described for Prp39 and Prp40, except $100 \mu \mathrm{M}$ IPTG was used for induction and the cell pellet was resuspended in pull-down buffer $(20 \mathrm{mM}$ Hepes at $\mathrm{pH}$ 7.2, $200 \mathrm{mM}$ potassium acetate, $2 \mathrm{mM}$ magnesium acetate, $0.5 \%$ Tween 20,1 $\mathrm{mM}$ DTT $)$. After two clearing spins at $4^{\circ} \mathrm{C}(10 \mathrm{~min}$ each at 10,000 rcf), GST-Prp8-NTD lysate was frozen in liquid nitrogen and stored at $-80^{\circ} \mathrm{C}$ for up to $3 \mathrm{mo}$. For pull-downs, $100 \mu \mathrm{L}$ of GST fusion protein lysate per sample was added to $25 \mu \mathrm{L}$ of a $50 \%$ slurry of glutathione-Sepharose 4 fast flow (GE Healthcare). For Prp 28 pull-downs, 25 $\mu \mathrm{L}$ of GST fusion protein plus $75 \mu \mathrm{L}$ pull-down buffer was used. GST fusion protein was shown to be in saturating amounts by checking the supernatant by Western blot for residual GST-tagged protein after incubation (data not shown). Following $1 \mathrm{~h}$ incubation at $4^{\circ} \mathrm{C}$, supernatants were removed, the beads were washed twice with pulldown buffer and used for the pull-down assay. Purified $\mathrm{His}_{6}$-fusion proteins were added in $350 \mu \mathrm{L}$ pull-down buffer and incubated for $3 \mathrm{~h}$ at $4^{\circ} \mathrm{C}$ with rotation. Beads were then washed $4 \times$ with pulldown buffer $\left(4^{\circ} \mathrm{C}\right.$ for Prp39 and Prp40, room temperature for Prp28), spun for $1 \mathrm{~min}$ at $750 \mathrm{rcf}$, and boiled with $30 \mu \mathrm{L} 2 \mathrm{x}$ SDS sample buffer. Samples were analyzed by Western blot, detecting bound His $_{6}$-fusion Prp39 or Prp40 with mouse-anti-His 5 serum (Qiagen), then goat-anti-mouse IgG IR-Dye 680 (LI-COR Biosciences). Bound Prp28 was detected with anti-Prp28 antibody (Strauss and Guthrie 1994), then goat-anti-mouse-HRP secondary antibody (Biorad), and detected by Amersham ECL (GE Healthcare). Equal loading of GST-fusion proteins was checked either by Ponceau stain prior to blocking or detection with goat-anti-GST antiserum (Pharmacia), then donkey anti goat-HRP (Santa Cruz) and ECL.

\section{Microarray analysis of in vivo splicing defects}

Microarray samples were prepared essentially as in Pleiss et al. (2007). Briefly, strains AMP25-28 were grown in YEPD at $30^{\circ} \mathrm{C}$ to $\mathrm{OD}_{600} 0.4-0.5$, then shifted to $16^{\circ} \mathrm{C}$ for $50 \mathrm{~min}$. Cells from $15 \mathrm{~mL}$ of culture were collected by centrifugation. cDNA was prepared from $50 \mu \mathrm{g}$ of total cell RNA using random 9-mer primers and labeled with Cy3 or Cy5. Labeled cDNA from each mutant was competitively hybridized to the array with cDNA from wildtype or another mutant as indicated in Figure 3. Arrays were analyzed as in Plocik and Guthrie (2012). The results presented are the average of two biological replicates, each with a dye-flipped technical replicate.

\section{Chromatin immunoprecipitation and quantitative PCR (ChIP-qPCR)}

ChIP-qPCR analysis of the genes ECM33 and SEC27 was done essentially as described (Görnemann et al. 2005). To cross-link splic- ing factors to DNA, $4.0 \mathrm{~mL} 37 \%$ formaldehyde solution was added to $150 \mathrm{~mL}$ yeast culture, incubated for $15 \mathrm{~min}$ at room temperature, then quenched by addition of $8.1 \mathrm{~mL} 2.5 \mathrm{M}$ glycine. For parallel analyses at permissive and nonpermissive temperatures, cells were grown in $200 \mathrm{~mL} \mathrm{YPD}$ at $30^{\circ} \mathrm{C}$ to an $\mathrm{OD}_{600}$ of $0.6-0.8$. The cultures were divided, $100 \mathrm{~mL}$ added to $50 \mathrm{~mL} 30^{\circ} \mathrm{C}$ YPD or $4^{\circ} \mathrm{C} \mathrm{YPD}$, and incubated for $45 \mathrm{~min}$ at $30^{\circ} \mathrm{C}$ or $16^{\circ} \mathrm{C}$, respectively, before crosslinking. Cells were harvested by centrifugation at $3500 \mathrm{~g}$ for $5 \mathrm{~min}$, washed twice with PBS, and then frozen. Cell pellets were thawed on ice, resuspended in $1 \mathrm{~mL}$ buffer FA-1 (50 mM HEPES-KOH at $\mathrm{pH}$ 7.5, $140 \mathrm{mM} \mathrm{NaCl}, 1 \mathrm{mM}$ EDTA, 1\% Triton-X 100, $0.1 \%$ sodium deoxycholate) and lysed on a Vortex Disruptor Genie with glass beads for $40 \mathrm{~min}$ at $4^{\circ} \mathrm{C}$ at maximum speed. Lysates were recovered, including two washes of the glass beads with 1 mL FA-1 each and subjected to sonication on ice to fragment the chromatin to an average of $500 \mathrm{bp}$. With the 250D Sonifier Ultrasonic Processor Cell Disruptor (Branson) used, this required $6 \mathrm{~min}$ of 15 -sec on/off cycles at 30\% intensity. Lysates were subsequently cleared by centrifugation at $3500 \mathrm{~g}$ for $5 \mathrm{~min}$. Supernatants were cleared prior to immunoprecipitation by addition of $200 \mu \mathrm{L}$ of a $50 \%$ slurry of Sepharose CL-4B beads (Sigma-Aldrich), previously washed with FA-1 buffer, and rotation at $4^{\circ} \mathrm{C}$ for $1 \mathrm{~h}$. Eight micrograms of 12CA5 antibody was then added to $700 \mu \mathrm{L}$ of lysate, followed by rotation at $4^{\circ} \mathrm{C}$ for $2 \mathrm{~h}$, then $50 \mu \mathrm{L}$ of washed GammaBind G beads (GE Healthcare) were added for $1 \mathrm{~h}$. Mouse IgG (Sigma) served as a negative control. Beads were washed three times with buffer FA-1, once each with buffer FA-2 (FA-1 with $500 \mathrm{mM} \mathrm{NaCl})$ and FA-3 $(20 \mathrm{mM}$ Tris- $\mathrm{Cl}$ at $\mathrm{pH} 8.0,250 \mathrm{mM}$ LiCl, 0.5\% NP-40, 0.5\% sodium deoxycholate, 1 mM EDTA), and twice with TE buffer ( $\mathrm{pH} 8.0$ ), transferring the beads to a fresh tube. For elution and uncross-linking, $250 \mu \mathrm{L}$ TE/1\% SDS was added, followed by incubation at $65^{\circ} \mathrm{C}$ overnight. In parallel, $20 \mu \mathrm{L}$ of lysate in $200 \mu \mathrm{L} \mathrm{TE} / 1 \%$ SDS was uncross-linked to serve as input control. Eluates were transferred to a fresh tube, incubated with $10 \mu \mathrm{L}$ Proteinase $\mathrm{K}(20 \mathrm{mg} / \mathrm{mL})$ at $55^{\circ} \mathrm{C}$ for $2 \mathrm{~h}$, and purified with a PCR purification kit according to instructions (Qiagen). The data in Figure 4 represent the average of three independent experiments, except: $\operatorname{Prp} 42$ (all strains): $n=4$; prp28-1-Brr2 at $16^{\circ} \mathrm{C}$ and $30^{\circ} \mathrm{C}: n=6$; prp $28-1+\operatorname{prp} 8-P 263 L / W 279 G-B r r 2$ at $16^{\circ} \mathrm{C}$ and $30^{\circ} \mathrm{C}: n=4$; Msl1, Brr2, Prp19 in WT: $n=4$.

\section{Primers used for ChIP-qPCR}

ECM-UP-F: GCAGTATCATCCTTCACGACCC; ECM-UP-R: GCG TCTTTCCCGTTTTTGC; ECM9-31: CAAGAACGCTTTGACTGC TACTG; ECM145-123: GAAGAGGACCACGAATCTACTCG; ECM 430-451: ACTTCTGCCACTGCTACTGCTC; ECM562-539: AGG AACCATCAATCTCTTGGATAC; ECM1073-1097: TTGGTCAAT CTTTGTCTATCGTCTC; ECM1173-1150: TGTGTTGTTAGCAA TGATGAAACC; ECM1531-1555: TCTAAGAAGTCTAAGGGTGC TGCTC; ECM1582-1561: TGAATGAAGTGGCTGGAACAAG; SE C280-304: GGGTTTTGACTACCTTGTACTCTGG; SEC370-349: GGAGTTTCCGTAACTTGGATGG; SEC931-950: TTTCTGGTT CCGAAGATGGC; SEC1043-1022: TGTTGGATGGGTAGCGATA CAC; SEC1309-1330: TTGTTACAGTTGTTGGGGATGG; SEC 1395-1372: CAAAGTCTTGACATTTACCGAAGG; SEC1969-1992: GAGAGGTCCATGTTTATGGTTACG; SEC2057-2037: AATGGC TTCTTCAATTTCCCC; SEC2599-2622: CTGTATCAGAAAGAG TTTGTGGGG; SEC2692-2669: GCTGGAGTGGAATCTAAGTC AATG. 


\section{In vitro splicing extract preparation}

A total of 2-3-L cultures of strains AMP25-28 were harvested at $\mathrm{OD}_{600}$ 1.7-1.9, and splicing extract was prepared as described (Umen and Guthrie 1995), except that frozen cell pellets were ground with a ball mill (Retch MM 301 mixer-mill; $3 \times 3 \mathrm{~min}$ at $11 \mathrm{~Hz}$ and $2 \times 3 \mathrm{~min}$ at $12 \mathrm{~Hz}$ ) and dialyzed twice in $2 \mathrm{~L}$ buffer D. Prp28-depleted extract was made from strain PR88 (a gift from P. Raghunathan) in which genomic PRP28 is deleted and complemented by a plasmid with the GAL10 promoter controlling a copy of PRP28 with a 3x HA tag inserted in the ClaI site near the start codon of PRP28. The strain was grown to an $\mathrm{OD}_{600}$ of 0.5-0.7 in YEPgalactose, then filtered and shifted to YEPD for 3.5-5 h. Cells were collected and splicing extract prepared as above. Extracts were checked by Western blot with anti-HA antibody to confirm that Prp28 was no longer detectable.

\section{Biotinylated pre-mRNA pull-down experiments}

Biotinylated pre-mRNA pull-down experiments were adapted from previous protocols (Ruby et al. 1990; Kuhn et al. 1999; Staley and Guthrie 1999; Brenner and Guthrie 2006). Actin $\Delta 6$ pre-mRNA (Vijayraghavan et al. 1986) was synthesized with Megascript T7 RNA polymerase (Ambion) using biotin-11-UTP (Ambion) as 5\% of the UTP. Seven pull-down time course experiments were conducted using four different extract preparations from each of the four strains (AMP25-28); 120-140 $\mu \mathrm{L}$ splicing reactions were prepared; $1.9 \mu \mathrm{L}$ was taken for a " 0 min input" sample, and in three experiments, a $19-\mu \mathrm{L}$ "no pre-mRNA" sample was removed to $50 \mu \mathrm{L}$ stop buffer for background pull-down measurement (shown as " -5 min" time point). Reactions were started by adding $2.5 \mathrm{fmol}$ pre$\mathrm{mRNA} / \mu \mathrm{L}$ and ATP to $2 \mathrm{mM}$ final concentration, and were incubated at $16^{\circ} \mathrm{C}$. Twenty microliter aliquots were removed at indicated times, added to $50 \mu \mathrm{L}$ ice cold stop buffer (20 mM EDTA, $40 \%$ Buffer D, $60 \mathrm{mM} \mathrm{KPO}_{4}$ at pH 7, 3\% PEG 8000), and incubated on ice until the end of the time course. A 2- $\mu \mathrm{L}$ "input" sample was taken at $30 \mathrm{~min}$. A total of $50 \mu \mathrm{L}$ of streptavidin-agarose beads (Thermo Scientific) (50\% slurry in stop buffer, after being blocked in stop buffer plus $10 \mu \mathrm{g} / \mathrm{mL}$ each glycogen, tRNA, and bovine serum albumin) were added to each reaction except inputs, and incubated at $4^{\circ} \mathrm{C}$, rocking for $1 \mathrm{~h}$. For most experiments, $100 \mu \mathrm{L}$ wash buffer $\left(150 \mathrm{mM} \mathrm{NaCl}, 60 \mathrm{mM}\right.$ HEPES at $\mathrm{pH} 7.6,3 \mathrm{mM} \mathrm{MgCl}_{2}$, $15 \%$ glycerol, $0.05 \%$ NP40, 0.5 mM DTT) was added before supernatant was removed. Beads were then washed $3 \times$ with $500 \mu \mathrm{L}$ wash buffer. snRNAs and pre-mRNA were eluted by adding $50 \mu \mathrm{L}$ formamide $+40 \mathrm{mM}$ EDTA and incubating at $90^{\circ} \mathrm{C}$ for $\sim 10$ min followed by washing beads with 50 or $100 \mu \mathrm{L} \mathrm{TE}+1 \%$ SDS. In two experiments, RNA was instead eluted from beads with Proteinase $\mathrm{K}$ as in Kuhn et al. (1999). Input samples were added to $5 \mu \mathrm{L}$ stop buffer, and were incubated on ice until the elution step, at which point they were treated the same as pull-down samples. RNA was then phenolchloroform extracted, ethanol precipitated, and resuspended in 20 $\mu \mathrm{L} \mathrm{H}_{2} \mathrm{O}$. Eight microliters of RNA were reverse transcribed with primers specific to the snRNAs as described in Brenner and Guthrie (2006) and detected with qPCR as described, except the standard curve was generated from serial dilutions of a pool of input samples. qPCR values used are the average of 2-3 qPCR technical replicates.

qPCR values from each individual time course were normalized to the average of the respective 0 and 30-min input samples. All of the values in a single experiment (time courses with all four extracts done in parallel) were further normalized to the maximum value for that experiment, which allowed all experiments to be averaged together. In three of the experiments, 1 - and 2-min time points were taken instead of 1.5 and $3 \mathrm{~min}$. In order to include data from all repeats, 1.5- and 3-min values were interpolated, assuming a linear trend between 1 and $5 \mathrm{~min}$. Similarly, in one experiment the 30 -min value was interpolated from 25 - and 50-min time points, and the 50-min measurement was used as an approximation of the 60 -min point. These interpolated values were included in data for Figure 2, but leaving them out did not significantly change the results. Including interpolated values, $n=7$ for $1.5,3,5,10,15$, and $30 \mathrm{~min}$, and $n=6$ for $60 \mathrm{~min}$. Exceptions: wt $30 \mathrm{~min}: n=6$; prp8-tes 30 min: $n=6$, prp28-1 5, 10, and 30 min: $n=6$, prp28-1/ prp8-tes 1.5 min: $n=6$, background (no pre-mRNA added " -5 min"): $n=3$. Error, SEM of final values after all described normalization.

\section{Native gel analysis}

Commitment complex gels were based on a published protocol (Seraphin and Rosbash 1989). Twenty-two-microliter standard splicing reactions (Lin et al. 1985) containing $8.8 \mu \mathrm{L}$ of extract were depleted of ATP by adding glucose to $2 \mathrm{mM}$ and incubating at $25^{\circ} \mathrm{C}$ for $20 \mathrm{~min}$. A total of $1-2 \mu \mathrm{L}(\sim 15 \mathrm{fmol}$ or $\sim 30,000 \mathrm{cpm})$ radiolabeled RP51A $\Delta 2$ pre-mRNA (Seraphin and Rosbash 1991) was added to each reaction, and reactions were incubated for 20 min at $16^{\circ} \mathrm{C}$. Ten microliters was removed to $10 \mu \mathrm{L}$ ice cold buffer R (2 mM MgOAc, 50 mM Hepes ( $\mathrm{pH} 7.5), 1 \mathrm{mg} / \mathrm{mL}$ tRNA, 50fold molar excess cold Ubc4 or Actin pre-mRNA). Then, ATP (to $2 \mathrm{mM}$ ) was added to the remaining reaction volume, and reactions were incubated for another $20 \mathrm{~min}$ at $16^{\circ} \mathrm{C}$ before the final $10 \mu \mathrm{L}$ was removed to $10 \mu \mathrm{L}$ ice cold buffer R. Five microliters of loading dye (2.5x TBE, 50\% glycerol, bromophenol blue, and xylene cyanol dyes) was added, and the reaction was loaded on a $0.5 \mathrm{x}$ TBE, $3 \%$ acrylamide, $0.5 \%$ agarose, $5 \%$ glycerol gel, with a plug of $10 \%$ acrylamide gel at the bottom $\sim 3 \mathrm{~cm}(1 \mathrm{x}$ TBE $=89 \mathrm{mM}$ Tris-borate, $2 \mathrm{mM}$ EDTA). The $26-\mathrm{cm}$ gel was run in $0.5 \mathrm{x}$ TBE at $120 \mathrm{~V}$ for $20-24 \mathrm{~h}$ at $4^{\circ}$ C. Bands were detected by PhosphorImager (Molecular Dynamics) and quantified with ImageQuant v.5.2 (Molecular Dynamics). Error bars in Figure 6 show SEM from $n=5$ (-ATP: prp28 $\Delta$ ), $n=$ 6 (+ATP: prp28 $\Delta$ ), $n=8$ (-ATP: wt, prp28-1, prp28-1/prp8-tes), $n=9$ (-ATP: prp8-tes), $n=11$ (+ATP: prp28-1/prp8-tes), or $n=$ 12 (+ATP: wt, prp8-tes, prp28-1) replicates. To determine whether the CC2:CC1 ratio was different between prp28-1 and prp28-1/ prp8-tes, we conducted a paired $t$-test, pairing reactions that were prepared together and run on the same gel.

\section{DATA DEPOSITION}

Microarray data generated in this study are available for download from the Gene Expression Omnibus (GEO), under accession no. GSE42754.

\section{SUPPLEMENTAL MATERIAL}

Supplemental material is available for this article. 


\section{ACKNOWLEDGMENTS}

We thank Karla Neugebauer for supporting the ChIP experiments, Thomas Hoffmann for data analysis advice, Matthew Kahlscheuer and Nils Walter for the Prp28 expression plasmid, members of the Brow and Guthrie labs for helpful suggestions, and Sam Butcher, Tien-Hsien Chang, Charles Query, and Joan Steitz for comments on the manuscript. This study was supported by an NSF GRFP fellowship to A.M.P., a postdoctoral fellowship from the Deutsche Forschungsgemeinschaft to J.G., and NIH grants to D.A.B. and C.G. C.G. is an American Cancer Society Research Professor of Molecular Genetics. This work is dedicated to the memory of Stephanie W. Ruby, who did pioneering studies on the role of U1 snRNP in spliceosome assembly.

Received August 14, 2013; accepted October 17, 2013.

\section{REFERENCES}

Abovich N, Rosbash M. 1997. Cross-intron bridging interactions in the yeast commitment complex are conserved in mammals. Cell 89: 403-412.

Ast G, Weiner AM. 1997. A novel U1/U5 interaction indicates proximity between U1 and U5 snRNAs during an early step of mRNA splicing. RNA 3: 371-381.

Brenner TJ, Guthrie C. 2006. Assembly of Snu114 into U5 snRNP requires Prp8 and a functional GTPase domain. RNA 12: 862-871.

Brow DA. 2002. Allosteric cascade of spliceosome activation. Annu Rev Genet 36: 333-360.

Burgess SM, Guthrie C. 1993. A mechanism to enhance mRNA splicing fidelity: The RNA-dependent ATPase Prp16 governs usage of a discard pathway for aberrant lariat intermediates. Cell 73: 13771391.

Chen JY-F, Stands L, Staley JP, Jackups RR Jr, Latus LJ, Chang T-H. 2001. Specific alterations of U1-C protein or U1 small nuclear RNA can eliminate the requirement of Prp28p, an essential DEAD box splicing factor. Mol Cell 7: 227-232.

Dlakić M, Mushegian A. 2011. Prp8, the pivotal protein of the spliceosomal catalytic center, evolved from a retroelement-encoded reverse transcriptase. RNA 17: 799-808.

Fabrizio P, Dannenberg J, Dube P, Kastner B, Stark H, Urlaub H, Lührmann R. 2009. The evolutionarily conserved core design of the catalytic activation step of the yeast spliceosome. Mol Cell 36: 593-608.

Fairman-Williams ME, Guenther U-P, Jankowsky E. 2010. SF1 and SF2 helicases: Family matters. Curr Opin Struct Biol 20: 313-324.

Filippakopoulos P, Knapp S. 2012. The bromodomain interaction module. FEBS Lett 586: 2692-2704.

Galej WP, Oubridge C, Newman AJ, Nagai K. 2013. Crystal structure of Prp8 reveals active site cavity of the spliceosome. Nature 493: 638643.

Görnemann J, Kotovic KM, Hujer K, Neugebauer KM. 2005. Cotranscriptional spliceosome assembly occurs in a stepwise fashion and requires the cap binding complex. Mol Cell 19: 53-63.

Görnemann J, Barrandon C, Hujer K, Rutz B, Rigaut G, Kotovic KM, Faux C, Neugebauer KM, Séraphin B. 2011. Cotranscriptional spliceosome assembly and splicing are independent of the Prp40p WW domain. RNA 17: 2119-2129.

Gottschalk A, Neubauer G, Banroques J, Mann M, Lührmann R, Fabrizio P. 1999. Identification by mass spectrometry and functional analysis of novel proteins of the yeast [U4/U6.U5] tri-snRNP. EMBO J 18: 4535-4548.

Gottschalk A, Kastner B, Lührmann R, Fabrizio P. 2001. The yeast U5 snRNP coisolated with the U1 snRNP has an unexpected protein composition and includes the splicing factor Aar2p. RNA 7: 15541565 .
Grainger RJ, Beggs JD. 2005. Prp8 protein: At the heart of the spliceosome. RNA 11: 533-557.

Guan KL, Dixon JE. 1991. Eukaryotic proteins expressed in Escherichia coli: An improved thrombin cleavage and purification procedure of fusion proteins with glutathione S-transferase. Anal Biochem 192: 262-267.

Hage R, Tung L, Du H, Stands L, Rosbash M, Chang T-H. 2009. A targeted bypass screen identifies Ynl187p, Prp42p, Snu71p, and Cbp80p for stable U1 snRNP/Pre-mRNA interaction. Mol Cell Biol 29: 3941-3952.

Hartmuth K, Urlaub H, Vornlocher H-P, Will CL, Gentzel M, Wilm M, Lührmann R. 2002. Protein composition of human prespliceosomes isolated by a tobramycin affinity-selection method. Proc Natl Acad Sci 99: 16719-16724.

Hoskins AA, Friedman LJ, Gallagher SS, Crawford DJ, Anderson EG, Wombacher R, Ramirez N, Cornish VW, Gelles J, Moore MJ. 2011. Ordered and dynamic assembly of single spliceosomes. Science 331: 1289-1295.

Ismaili N, Sha M, Gustafson EH, Konarska MM. 2001. The 100-kDa U5 snRNP protein (hPrp28p) contacts the $5^{\prime}$ splice site through its ATPase site. RNA 7: 182-193.

Kistler AL, Guthrie C. 2001. Deletion of MUD2, the yeast homolog of U2AF65, can bypass the requirement for Sub2, an essential spliceosomal ATPase. Genes Dev 15: 42-49.

Knop M, Siegers K, Pereira G, Zachariae W, Winsor B, Nasmyth K, Schiebel E. 1999. Epitope tagging of yeast genes using a PCR-based strategy: More tags and improved practical routines. Yeast 15: 963-972.

Kosowski TR, Keys HR, Quan TK, Ruby SW. 2009. DExD/H-box Prp5 protein is in the spliceosome during most of the splicing cycle. RNA 15: 1345-1362.

Kotovic KM, Lockshon D, Boric L, Neugebauer KM. 2003. Cotranscriptional recruitment of the U1 snRNP to intron-containing genes in yeast. Mol Cell Biol 23: 5768-5779.

Kuhn AN, Brow DA. 2000. Suppressors of a cold-sensitive mutation in yeast U4 RNA define five domains in the splicing factor Prp8 that influence spliceosome activation. Genetics 155: 1667-1682.

Kuhn AN, Li Z, Brow DA. 1999. Splicing factor Prp8 governs U4/U6 RNA unwinding during activation of the spliceosome. Mol Cell 3: 65-75.

Kuhn AN, Reichl EM, Brow DA. 2002. Distinct domains of splicing factor Prp8 mediate different aspects of spliceosome activation. Proc Natl Acad Sci 99: 9145-9149.

Lacadie SA, Rosbash M. 2005. Cotranscriptional spliceosome assembly dynamics and the role of U1 snRNA:5'ss base pairing in yeast. Mol Cell 19: 65-75.

Lacadie SA, Tardiff DF, Kadener S, Rosbash M. 2006. In vivo commitment to yeast cotranscriptional splicing is sensitive to transcription elongation mutants. Genes Dev 20: 2055-2066.

Lesser CF, Guthrie C. 1993. Mutational analysis of pre-mRNA splicing in Saccharomyces cerevisiae using a sensitive new reporter gene, CUP1. Genetics 133: 851-863.

Li X, Zhang W, Xu T, Ramsey J, Zhang L, Hill R, Hansen KC, Hesselberth JR, Zhao R. 2013. Comprehensive in vivo RNA-binding site analyses reveal a role of Prp8 in spliceosomal assembly. Nucleic Acids Res 41: 3805-3818.

Libri D, Graziani N, Saguez C, Boulay J. 2001. Multiple roles for the yeast SUB2/yUAP56 gene in splicing. Genes Dev 15: 36-41.

Lin RJ, Newman AJ, Cheng SC, Abelson J. 1985. Yeast mRNA splicing in vitro. J Biol Chem 260: 14780-14792.

Maeder C, Kutach AK, Guthrie C. 2008. ATP-dependent unwinding of U4/U6 snRNAs by the Brr2 helicase requires the C terminus of Prp8. Nat Struct Mol Biol 16: 42-48.

Maroney PA, Romfo CM, Nilsen TW. 2000. Functional recognition of the $5^{\prime}$ splice site by U4/U6.U5 tri-snRNP defines a novel ATPdependent step in early spliceosome assembly. Mol Cell 6: 317328.

Mathew R, Hartmuth K, Möhlmann S, Urlaub H, Ficner R, Lührmann R. 2008. Phosphorylation of human PRP28 by SRPK2 is required 
for integration of the U4/U6-U5 tri-snRNP into the spliceosome. Nat Struct Mol Biol 15: 435-443.

Mozaffari-Jovin S, Santos KF, Hsiao H-H, Will CL, Urlaub H, Wahl MC, Lührmann R. 2012. The Prp8 RNase H-like domain inhibits Brr2mediated U4/U6 snRNA unwinding by blocking Brr2 loading onto the U4 snRNA. Genes Dev 26: 2422-2434.

Mozaffari-Jovin S, Wandersleben T, Santos KF, Will CL, Lührmann R, Wahl MC. 2013. Inhibition of RNA helicase Brr2 by the C-terminal tail of the spliceosomal protein Prp8. Science 341: 80-84.

Newman AJ, Teigelkamp S, Beggs JD. 1995. snRNA interactions at $5^{\prime}$ and $3^{\prime}$ splice sites monitored by photoactivated crosslinking in yeast spliceosomes. RNA 1: 968-980.

Pena V, Liu S, Bujnicki JM, Lührmann R, Wahl MC. 2007. Structure of a multipartite protein-protein interaction domain in splicing factor Prp8 and its link to retinitis pigmentosa. Mol Cell 25: 615-624.

Pena V, Rozov A, Fabrizio P, Lührmann R, Wahl MC. 2008. Structure and function of an RNase $\mathrm{H}$ domain at the heart of the spliceosome. EMBO J 27: 2929-2940.

Perriman R, Barta I, Voeltz GK, Abelson J, Ares M. 2003. ATP requirement for Prp5p function is determined by Cus $2 p$ and the structure of U2 small nuclear RNA. Proc Natl Acad Sci 100: 13857-13862.

Pleiss JA, Whitworth GB, Bergkessel M, Guthrie C. 2007. Transcript specificity in yeast pre-mRNA splicing revealed by mutations in core spliceosomal components. PLoS Biol 5: e90.

Plocik AM, Guthrie C. 2012. Diverse forms of RPS9 splicing are part of an evolving autoregulatory circuit. PLoS Genet 8: e1002620.

Raghunathan PL, Guthrie C. 1998. RNA unwinding in U4/U6 snRNPs requires ATP hydrolysis and the DEIH-box splicing factor Brr2. Curr Biol 8: 847-855.

Ritchie DB, Schellenberg MJ, Gesner EM, Raithatha SA, Stuart DT, MacMillan AM. 2008. Structural elucidation of a PRP8 core domain from the heart of the spliceosome. Nat Struct Mol Biol 15: 1199-1205.

Ruby SW, Goelz SE, Hostomsky Z, Abelson JN. 1990. Affinity chromatography with biotinylated RNAs. Methods Enzymol 181: 97-121.

Schellenberg MJ, Wu T, Ritchie DB, Fica S, Staley JP, Atta KA, LaPointe P, MacMillan AM. 2013. A conformational switch in PRP8 mediates metal ion coordination that promotes pre-mRNA exon ligation. Nat Struct Mol Biol 20: 728-734.

Schwer B, Chang J, Shuman S. 2013. Structure-function analysis of the $5^{\prime}$ end of yeast U1 snRNA highlights genetic interactions with the Ms15•Mud2 branchpoint-binding complex and other spliceosome assembly factors. Nucleic Acids Res 41: 7485-7500.

Seraphin B, Rosbash M. 1989. Identification of functional U1 snRNApre-mRNA complexes committed to spliceosome assembly and splicing. Cell 59: 349-358.

Seraphin B, Rosbash M. 1991. The yeast branchpoint sequence is not required for the formation of a stable U1 snRNA-pre-mRNA complex and is recognized in the absence of U2 snRNA. EMBO $J$ 10: $1209-1216$.

Small EC, Leggett SR, Winans AA, Staley JP. 2006. The EF-G-like GTPase Snu114p regulates spliceosome dynamics mediated by Brr2p, a DExD/H box ATPase. Mol Cell 23: 389-399.
Staley JP, Guthrie C. 1999. An RNA switch at the $5^{\prime}$ splice site requires ATP and the DEAD box protein Prp28p. Mol Cell 3: 55-64.

Stevens SW, Barta I, Ge HY, Moore RE, Young MK, Lee TD, Abelson J. 2001. Biochemical and genetic analyses of the U5, U6, and U4/ U6.U5 small nuclear ribonucleoproteins from Saccharomyces cerevisiae. RNA 7: 1543-1553.

Strauss EJ, Guthrie C. 1991. A cold-sensitive mRNA splicing mutant is a member of the RNA helicase gene family. Genes Dev 5: 629-641.

Strauss EJ, Guthrie C. 1994. PRP28, a "DEAD-box" protein, is required for the first step of mRNA splicing in vitro. Nucleic Acids Res 22: 3187-3193.

Teigelkamp S, Mundt C, Achsel T, Will CL, Lührmann R. 1997. The human U5 snRNP-specific $100-\mathrm{kD}$ protein is an RS domain-containing, putative RNA helicase with significant homology to the yeast splicing factor Prp28p. RNA 3: 1313-1326.

Umen JG, Guthrie C. 1995. A novel role for a U5 snRNP protein in $3^{\prime}$ splice site selection. Genes Dev 9: 855-868.

Umen JG, Guthrie C. 1996. Mutagenesis of the yeast gene PRP8 reveals domains governing the specificity and fidelity of $3^{\prime}$ splice site selection. Genetics 143: 723-739.

van Nues RW, Beggs JD. 2001. Functional contacts with a range of splicing proteins suggest a central role for Brr2p in the dynamic control of the order of events in spliceosomes of Saccharomyces cerevisiae. Genetics 157: 1451-1467.

Vijayraghavan U, Parker R, Tamm J, Iimura Y, Rossi J, Abelson J, Guthrie C. 1986. Mutations in conserved intron sequences affect multiple steps in the yeast splicing pathway, particularly assembly of the spliceosome. EMBO J 5: 1683-1695.

Wassarman DA, Steitz JA. 1992. Interactions of small nuclear RNA's with precursor messenger RNA during in vitro splicing. Science 257: 1918-1925.

Weber G, Cristão VF, De L, Alves F, Santos KF, Holton N, Rappsilber J, Beggs JD, Wahl MC. 2011. Mechanism for Aar2p function as a U5 snRNP assembly factor. Genes Dev 25: 1601-1612.

Will CL, Lührmann R. 2011. Spliceosome structure and function. Cold Spring Harb Perspect Biol 3: a003707.

Wyatt JR, Sontheimer EJ, Steitz JA. 1992. Site-specific cross-linking of mammalian U5 snRNP to the $5^{\prime}$ splice site before the first step of pre-mRNA splicing. Genes Dev 6: 2542-2553.

Xu Y-Z, Newnham CM, Kameoka S, Huang T, Konarska MM, Query CC. 2004. Prp5 bridges U1 and U2 snRNPs and enables stable U2 snRNP association with intron RNA. EMBO J 23: 376385.

Yang K, Zhang L, Xu T, Heroux A, Zhao R. 2008. Crystal structure of the B-finger domain of Prp8 reveals analogy to ribosomal proteins. Proc Natl Acad Sci 105: 13817-13822.

Yang F, Wang X-Y, Zhang Z-M, Pu J, Fan Y-J, Zhou J, Query CC, Xu YZ. 2013. Splicing proofreading at $5^{\prime}$ splice sites by ATPase Prp28p. Nucleic Acids Res 41: 4660-4670.

Zhang M, Green MR. 2001. Identification and characterization of yUAP/Sub2p, a yeast homolog of the essential human pre-mRNA splicing factor hUAP56. Genes Dev 15: 30-35. 

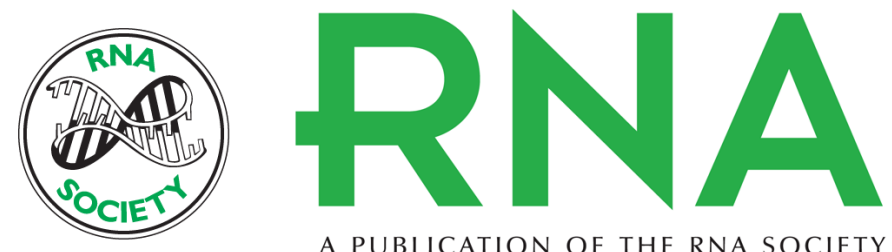

A PUBLICATION OF THE RNA SOCIETY

\section{An unanticipated early function of DEAD-box ATPase Prp28 during commitment to splicing is modulated by U5 snRNP protein Prp8}

Argenta M. Price, Janina Görnemann, Christine Guthrie, et al.

RNA 2014 20: 46-60 originally published online November 14, 2013

Access the most recent version at doi:10.1261/rna.041970.113

\section{Supplemental http://rnajournal.cshlp.org/content/suppl/2013/10/31/rna.041970.113.DC1 \\ Material}

References This article cites 70 articles, 38 of which can be accessed free at: http://rnajournal.cshlp.org/content/20/1/46.full.html\#ref-list-1

Creative This article is distributed exclusively by the RNA Society for the first 12 months after the Commons License full-issue publication date (see http://rnajournal.cshlp.org/site/misc/terms.xhtml). After 12 months, it is available under a Creative Commons License (Attribution-NonCommercial 3.0 Unported), as described at http://creativecommons.org/licenses/by-nc/3.0/.
Email Alerting Receive free email alerts when new articles cite this article - sign up in the box at the Service top right corner of the article or click here.

To subscribe to $R N A$ go to:

http://rnajournal.cshlp.org/subscriptions 